\title{
WestVirginiaUniversity
}

THE RESEARCH REPOSITORY @ WVU

Graduate Theses, Dissertations, and Problem Reports

2015

\section{The Role of Dynorphin in the Onset of Puberty in Female Lambs}

Justin Angelo Lopez

Follow this and additional works at: https://researchrepository.wvu.edu/etd

\section{Recommended Citation}

Lopez, Justin Angelo, "The Role of Dynorphin in the Onset of Puberty in Female Lambs" (2015). Graduate Theses, Dissertations, and Problem Reports. 6110.

https://researchrepository.wvu.edu/etd/6110

This Thesis is protected by copyright and/or related rights. It has been brought to you by the The Research Repository @ WVU with permission from the rights-holder(s). You are free to use this Thesis in any way that is permitted by the copyright and related rights legislation that applies to your use. For other uses you must obtain permission from the rights-holder(s) directly, unless additional rights are indicated by a Creative Commons license in the record and/ or on the work itself. This Thesis has been accepted for inclusion in WVU Graduate Theses, Dissertations, and Problem Reports collection by an authorized administrator of The Research Repository @ WVU. For more information, please contact researchrepository@mail.wvu.edu. 
The Role of Dynorphin in the Onset of Puberty in Female Lambs

by

Justin Angelo Lopez

Thesis submitted to the Davis College of Agriculture, Natural Resources and Design at West Virginia University

in partial fulfillment of the requirements for the degree of

Master of Science

in

Reproductive Physiology

Robert L. Goodman, Ph.D., Chair

Stanley M. Hileman, Ph.D.

Robert A. Dailey, Ph.D.

Reproductive Physiology

Morgantown, West Virginia

2015

Keywords: sheep, puberty, dynoprhin, kisspeptin, KNDy

Copyright 2015 Justin Angelo Lopez 


\section{ABSTRACT \\ The Role of Dynorphin in the Onset of Puberty in Female Lambs}

\section{Justin Angelo Lopez}

The neural mechanisms underlying the onset of puberty are not well understood. In sheep, this process involves an increase in GnRH release due to decreased sensitivity to estrogen feedback. Because GnRH neurons do not express the relevant estrogen receptors,

this pathway must contain interneurons. Neurons in the arcuate nucleus (ARC) of the hypothalamus that co-express kisspeptin (Kiss), neurokinin B (NKB), and dynorphin (DYN), i.e. KNDy neurons, play a critical role. Based on previous data, the overall hypothesis is that the prepubertal hold in GnRH/LH release results from reduced Kiss stimulation and heightened DYN inhibition in response to estrogen negative feedback. Two experiments were performed to address this idea. The first experiment tested the hypothesis that Kiss expression would be increased and DYN expression decreased in response to ovariectomy (OVX). Prepubertal ewe lambs were randomly assigned to three groups: OVX $(n=5)$, OVX and treated with estrogen $(\mathrm{OVX}+\mathrm{E})(\mathrm{n}=5)$, or left ovary-intact $(n=4)$. As hypothesized, numbers of Kiss-immunoreactive cells in the ARC were increased by OVX (207.5 \pm 5.6 cells/section) compared to either ovary-intact $(110.6 \pm 2.7$ cells/section $)$ or $\mathrm{OVX}+\mathrm{E}(48.4 \pm 2.4$ cells/section $)$ groups and were significantly higher in ovary-intact compared to OVX+E females. Contrary to the hypothesis, very few DYNimmunopositive cells were found in the ARC of any treatment group, even though they were readily evident in control hypothalamic tissue concurrently assessed from adult ewes collected during the luteal phase $(29.8 \pm 3.9$ cells/section $)$. Although data regarding DYN were not consistent with the hypothesis, a role for DYN cannot be ruled out as the lack of staining could be reflective of high release rates of the peptide. Thus, a second study was performed to test the hypothesis that blockade of the $\kappa$-opioid receptor ( $\kappa-$ OR) (DYN's cognate receptor) would increase LH secretion in steroid-treated females of a prepubertal, but not postpubertal, age. Thus the effects of norbinaltorphimine (nor-BNI), a $\kappa-\mathrm{OR}$ antagonist, on LH secretion were compared between OVX + E prepubertal ewes $(n=6)$ and $\mathrm{OVX}+\mathrm{E}$ postpubertal ewes. Prepubertal OVX+E lambs were infused ICV $(60 \mathrm{ul} / \mathrm{h})$ with artificial cerebral spinal fluid (aCSF), as a control, or nor-BNI $(60 \mathrm{nmol} / \mathrm{h})$ for $3 \mathrm{~h}$. As hypothesized, administration of nor-BNI increased LH pulse frequency $(3.5 \pm 0.6 \mathrm{pulses} / 3$ $\mathrm{h}$ ) and mean $\mathrm{LH}(6.3 \pm 0.9 \mathrm{ng} / \mathrm{mL})$ compared to aCSF (frequency: $1.7 \pm 0.5$ pulses $/ 3 \mathrm{~h}$; mean: $3.2 \pm 0.7 \mathrm{ng} / \mathrm{mL}$ ). Nor-BNI or aCSF was infused for $4 \mathrm{~h}$ in these same OVX+E ewes at a postpubertal age. There were no significant differences in LH pulse frequency, mean LH, or LH pulse amplitude between treatments. These data demonstrate that inhibition by DYN is at least partly responsible for the prepubertal suppression of $\mathrm{GnRH} / \mathrm{LH}$ secretion by estrogen. Based on these data, it is suggested that increased stimulation by Kiss and reduced inhibition by DYN play important roles in the escape from estrogen negative feedback that underlies the transition to puberty in the female lamb. 


\section{DEDICATION}

I dedicate this thesis to my parents, Angel and Sheila Lopez, my brothers, Bryson and Kristian Lopez, and my Nonna, Carla Mann, for their love and support throughout all my years of college. 


\section{ACKNOWLEDGEMENTS}

Firstly, I would like to thank Dr. Robert Goodman and Dr. Stanley Hileman for their continuous support and advice throughout my graduate career, as well as through the process of completing this thesis. I thank Dr. Robert Dailey for his willingness to serve on my committee and his ability to always offer a different way of thinking about reproductive physiology. I would like to give special thanks to Dr. Alison Brown, Wingate University, for her guidance during my undergraduate career and assistance in finding and applying to this graduate program. I would also like to give special thanks to Dr. Sandra Petersen for the invaluable experience I received while training with her at the University of Massachusetts, Amherst.

I thank a previous graduate student, Dr. Katrina Porter, for always being an understanding and patient teacher, as well as my fellow graduate students, Richard McCosh and Michelle Bedenbaugh, and post-doctoral fellow, Dr. Pasha Grachev, for all their assistance with surgeries, blood collections, and animal handling in general, but more importantly for conversations to break up the monotony of desk work. The technical help of Dr. Miro Valent and Gail Nesselrod is gratefully appreciated; their contributions have made this process all the more possible. I also thank Dr. John Connors and Dr. Steve Hardy for their assistance with surgeries and Lanny Meadows, someday M.D., for the time he spent cutting tissue.

Thanks again to all of you who have helped me throughout my Master's Degree. I could not have succeeded without all of your support. God bless you all. 


\section{TABLE OF CONTENTS}

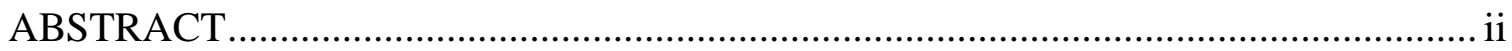

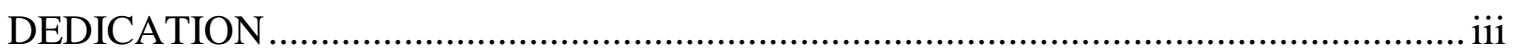

ACKNOWLEDGEMENTS .............................................................................. iv

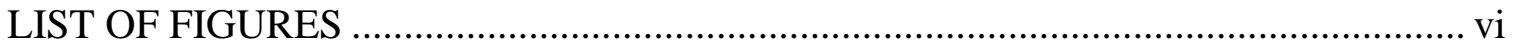

LIST OF NOMENCLATURE ............................................................................ vii

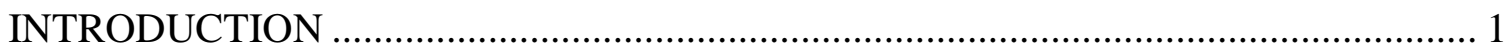

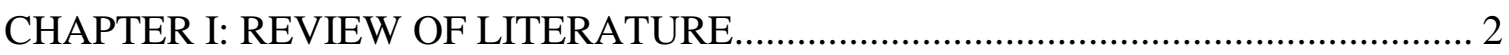

I. Endocrinology of Puberty .............................................................................. 2

II. Neural mechanisms involved in the onset of puberty of the prepubertal ewe lamb. 14

III. KNDy neurons and the initiation of puberty in the prepubertal ewe lamb............. 22

CHAPTER II: MATERIALS AND METHODS........................................................ 30

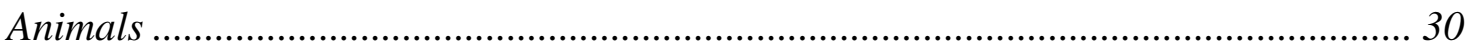

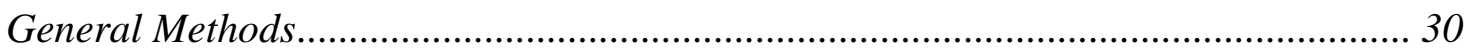

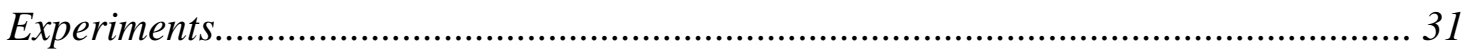

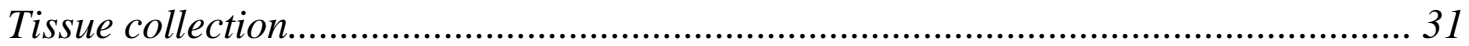

Single-label Immunocytochemistry for Kiss or DYN................................................ 33

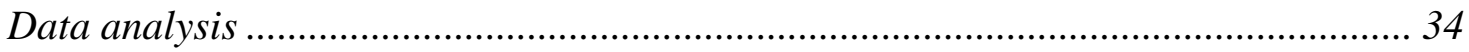

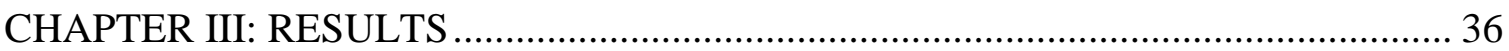

Experiment 1: Will changes in immunopositive Kiss/DYN cell numbers reflect changes in estrogen negative feedback? .................................................................................. 36 Experiment 2: Will administration of a k-opioid receptor antagonist into the lateral ventricle stimulate LH secretion? ......................................................................... 40

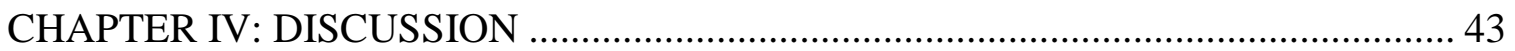

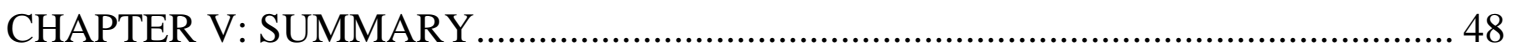

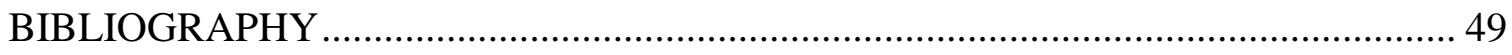

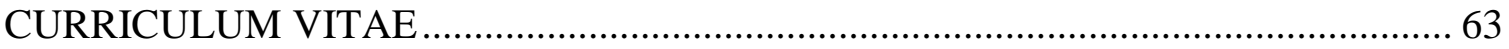




\section{LIST OF FIGURES}

Figure 1: Representative LH pulse profiles for individual females that were either ovaryintact, ovariectomized (OVX) or OVX and implanted with a 1-cm Silastic implant containing estradiol $(\mathrm{OVX}+\mathrm{E})$.

Figure 2: Mean \pm SEM for mean LH and number of LH pulses for ovary-intact, OVX, and $\mathrm{OVX}+\mathrm{E}$ female lambs that were prepubertal, peripubertal, or postpubertal. LH pulse amplitude is not shown because the low number of pulses in the intact and OVX+E group precluded comparisons amongst treatment groups.

Figure 3. Representative photomicrographs of Kiss within the ARC from prepubertal lambs that were ovary-intact, OVX, or OVX+E. Bar graphs depict Kiss cell numbers in the $\mathrm{ARC}$ of female lambs from the three treatment groups at three ages.

Figure 4: Representative photomicrographs of DYN within the ARC from prepubertal lambs that were ovary-intact, OVX, or OVX+E. A section of ARC from an adult ewe collected during the luteal phase is also shown as a positive control for DYN immunostaining.

Figure 5: Representative profiles of plasma LH concentrations after lateral ICV infusion of nor-BNI or aCSF for prepubertal lambs ovariectomized and implanted with estrogen $(\mathrm{OVX}+\mathrm{E}), \mathrm{OVX}+\mathrm{E}$ lambs also treated with a $\mathrm{CIDR}$ (progesterone) $(\mathrm{OVX}+\mathrm{E}+\mathrm{P})$, and $\mathrm{OVX}+\mathrm{E}$ postpubertal lambs.

Figure 6: Mean \pm SEM for mean LH, number of LH pulses, and LH pulse amplitude for prepubertal $\mathrm{OVX}+\mathrm{E}$, prepubertal $\mathrm{OVX}+\mathrm{E}+\mathrm{P}$, and postpubertal $\mathrm{OVX}+\mathrm{E}$ female lambs after lateral ventricle infusion of nor-BNI or aCSF. 


\section{LIST OF NOMENCLATURE}

2-DG, 2-deoxy-D-glucose

AgRP, agouti-related peptide

ARC, arcuate nucleus

AVPV, anteroventral periventricular nucleus

CNS, central nervous system

DYN, dynorphin

ER-a, estrogen receptor alpha

GH, growth hormone

GnRH, gonadotropin-releasing hormone

IGF-1, insulin-like growth factor

ICV/i.c.v., intracerebroventricular

K-OR, kappa-opioid receptor

Kiss, kisspeptin

Kiss1r/GPR-54, Kisspeptin receptor

KNDy, Kiss-NKB-DYN

LH, luteinizing hormone
$\mathbf{L V}$, lateral ventricle

MBH, mediobasal hypothalamus

MC3-R/MC4-R, melanocortin receptor

ME, median eminence

NK1R/NK2R/NK3R, tachykinin receptors

NKB, neurokinin B

NMA, $N$-methyl-D, L-aspartic acid

NMDA, $N$-methyl-D-aspartic acid

NPY, neuropeptide Y

OVX, ovariectomy

POA, preoptic area

POMC, proopiomelanocortin

$\mathbf{R C h}$, retrochiasmatic area

SCG, superior cervical ganglion

SCN, suprachiasmatic nucleus

$\boldsymbol{\alpha}$-MSH, melanocyte-stimulating hormone 


\section{INTRODUCTION}

Puberty is a complex series of events that is largely driven by the activation of the hypothalamic-pituitary-gonadal axis. Increase in pulsatile release of gonadotropinreleasing hormone $(\mathrm{GnRH})$ is a prerequisite for the initiation of pubertal development and sustainment of normal reproductive function throughout adulthood. The neural mechanisms underlying the rhythmic discharge of GnRH that results in the acquisition of sexual maturation still remains to be fully investigated. In a prepubertal state, the hypothalamus is highly sensitive to the inhibitory effects of estrogen, thus the secretion of $\mathrm{GnRH}$ is suppressed. Interestingly, GnRH neurons are devoid of estrogen receptor alpha (ER- $\alpha)$, the receptor whereby estrogen exerts negative effects, indicating the involvement

of intermediary neurons. Recent evidence suggests that neurons in the ARC that co-express Kiss, NKB, and DYN, i.e. KNDy neurons, play a critical role in activating sufficient hypothalamic release of $\mathrm{GnRH}$, resulting in the onset of puberty. 


\section{CHAPTER I: REVIEW OF LITERATURE}

\section{Endocrinology of Puberty}

Puberty is the process whereby an individual becomes capable of reproduction. In most mammalian species, this process is governed by a decrease in hypothalamic sensitivity to estrogen negative feedback as the individual transitions from the prepubertal period to adulthood (1-3). In the animal model used for studies in this thesis, ovis aries, the hypothalamus is highly sensitive to low levels of estradiol during the prepubertal period resulting in inhibition of gonadotropin-releasing hormone $(\mathrm{GnRH})$ secretion from the hypothalamus and thus suppression of luteinizing hormone (LH) secretion from the adenohypophysis (4). As immature female lambs grow and photoperiod requirements become permissive for reproduction, hypothalamic sensitivity to estrogen decreases, resulting in an increase in the frequency of pulsatile $\mathrm{GnRH}$ secretion and corresponding increases in LH pulse frequency. This increase in $\mathrm{GnRH} / \mathrm{LH}$ pulse frequency leads to increased ovarian follicular development and steroid production, eventually leading to a level of estrogen production that is sufficient to induce a surge of GnRH/LH secretion and first ovulation and, ultimately, sexual maturity (2).

\section{Sheep as an Animal Model}

The mechanisms underlying the initiation of the onset of puberty and subsequent sexual maturation in sheep often are compared to other well-studied animals, such as rodents and non-human primates. Although the models of "neuroendocrine puberty" are conceptually similar among these species, i.e. all require an increase in GnRH/LH pulse frequency, the underlying internal and external factors that influence the timing of that 
increase are complex and variable. First, lambs are relatively well-developed at birth and experience considerable development within the first weeks to months of age (5) in contrast to rats and primates, which are considered altricial species, relatively underdeveloped at birth. Because of these species differences, many developmental processes that happen postnatally in rats and primates occur prenatally in sheep. The pubertal progression that characterizes lambs allows in-depth study of various aspects of sexual maturation that are not as easily accomplished in other species. For example, given that the onset of puberty typically occurs at 6-7 months of age in lambs, there is a large window of time to study the progression of reproductive development in these animals. Another advantage, particularly when compared with rodents, rests in the size of the growing lamb. Thus, multiple series of intensive blood collection can be taken, which allow for definitive assessment of pulsatile GnRH/LH release. Moreover, the size and structure of neuroanatomical regions allows for precise placement of pharmacological treatments within the cerebroventricular system or the hypothalamus and for animals to serve as their own controls in designing experiments.

\section{The Energy Demand of Reproduction}

In most living organisms, sufficient somatic growth and energy availability are major determinants of timing of the onset of puberty and sexual maturation (5). These internal cues are critical, as it has been suggested that energy demands for thermoregulation and growth must be fulfilled before reproductive function can proceed in both males and females (6). As with other species, lambs at birth and throughout early postnatal development have a high ratio of surface area to body volume, leading to rapid heat loss and, consequently, increased metabolic demand to maintain core body temperature $(6,7)$. 
As such, newborn lambs are entirely dependent upon outside sources of nutrition, such as maternal lactation. The distribution of energetic intake largely favors thermoregulation and cellular maintenance, with the remaining energy allocated to muscular function and growth; understandably, reproductive function remains a low priority (7). As animals develop, the requirement for some metabolic functions decreases, and, as a result, body fat increases, while the ratio of surface area to volume decreases. The nutritional resources once used by these processes are now available for other physiological activities, such as reproductive function.

Although the importance of growth and sufficient energy availability to puberty onset has been well-established, there is a relative paucity of data regarding the sensors or pathways within the brain through which these important factors influence the timing of puberty. Studies by Kennedy et al., dating back to the early 1950's, manipulated growth rate in immature rats by chronic underfeeding to determine the effects on the onset of puberty. In these studies they found that energy availability plays a significant role in the timing of pubertal development, as evidenced by significant delays in the onset of puberty as a result of underfeeding. Additionally, they speculated that food intake signals may regulate the timing of sexual maturation and that the hypothalamus must be detecting these changes in somatic growth (5). These studies were succeeded by experiments administering high versus low-fat diets by Frisch et al. in the 1970's. In her studies she reported that immature rats fed a high-fat diet (fat substituted isocalorically for carbohydrates), experienced both vaginal opening and first estrus significantly earlier compared to animals in the low-fat diet group. She hypothesized that critical body composition for fatness must be met prior to the acquisition of puberty in immature rats 
(8), similar to what is reported in humans (9). Dietary restriction studies have now become a common method used to study the potential neural mechanisms that link nutrition and sexual maturation. How these pathways affect GnRH secretion is still not well understood; this is particularly true in sheep. Prepubertal female lambs maintained on a low calorie diet between 10 to 45 weeks of age failed to produce high-frequency LH pulses and initiate ovulation around the time of normally fed animals ( 30 weeks), and subsequent access to ad libitum feeding resulted in a relatively rapid increase in growth and expression of reproductive cycles shortly thereafter (10). Additionally, acute administration of high levels of estradiol induced LH surges in undernourished, ovariectomized lambs, yet chronic administration of estradiol resulted in a reduction in the magnitude of LH surges (10). Moreover, Foster et al., 1989, reported that prolonged restriction of daily caloric intake in lambs decreased LH pulse frequency and delayed puberty onset (11). These findings support the notion that undernourishment prevents high-frequency GnRH/LH pulses, and thus ovulation and reproductive cyclicity, in prepubertal female lambs. The sensors and neural mechanisms within the brain that integrate metabolic information are still an enigma; potential mechanisms involved in transducing metabolic information into signals that can influence GnRH release are discussed below.

\section{Leptin}

One candidate to link energy availability and reproduction is the adipokine protein, leptin. Leptin is a hormone synthesized and secreted from adipocytes that acts in the ARC to suppress appetite and increase energy expenditure, ultimately resulting in a loss of body weight (12). Leptin is also known to increase sympathetic outflow to brown adipose tissue (BAT), suggesting a role in the thermogenic actions of this tissue (13). Leptin rose to 
prominence when it was discovered to be absent in a mouse model of obesity and infertility, the $o b / o b$ mouse; peripheral administration of leptin to these mice reduced body weight and restored fertility (12). This is consistent with subsequent work showing that null or low levels of leptin in rats and humans are associated with significant delays in, or the absence of, puberty (14). In adult sheep, the rise and fall of leptin generally coincides with times of increased energy intake and reduced nutrient intake, respectively (15). Moreover, in rodents and non-human primates $(12,15,16)$, peripheral leptin levels increase during postnatal development. In these species, increases in LH occur earlier than vaginal opening in rats and menarche in primates, and, because of this, a lot of work has examined the temporal relationship between leptin and LH secretion during pubertal development. Suter et al., observed nocturnal increases in plasma leptin and growth hormone (GH)-induced insulin-like growth factor-1 (IGF-1) secretion that occurred just prior to nocturnal increases in plasma LH during the late prepubertal phase in agonadal primates; implicating leptin as a possible signal, in combination with other signals, for the initiation of puberty (16). This work, however, attracted some controversy, as some investigators suggested the method of arbitrarily assigning the "onset of puberty at day 0," when initial increases in LH were noted, and stating that data collected before the day 0 time point was in a prepubertal period and data collected after day 0 time point was in a peri-/postpubertal period might have been an inappropriate method to employ (17). They further argued that assigning such parameters to the age of puberty might not be accurate in defining the hypothalamic events leading to increased GnRH release necessary for puberty onset, as this information is unknown in primates (18). An additional study in rodents demonstrated that puberty onset, as defined by earlier occurrences of vaginal opening, estrus, and the onset of consistent 
estrous cycles, was advanced in immature female mice chronically treated with leptin injections (19). This group concluded that leptin essentially "informs" the hypothalamus that the body is now able to support sexual maturation (19). In a different study (20), leptin was administered to immature female rats, and the rate of sexual maturation was compared to two control groups. Leptin-treated rats, along with one control group, were fed ad libitum. A second control group was pair-fed to the leptin-treated group. As expected, food intake was significantly decreased in the leptin-treated group compared to the ad libitumfed control group, leading to stunted growth in the leptin-treated and pair-fed animals. The occurrence of pubertal indices (age at vaginal opening, age of first estrus, ovarian weight, uterine weight) was significantly delayed in pair-fed animals, while there was no difference between leptin-treated and ad libitum-fed control rats. When leptin-treated and pair-fed rats were fed at $70 \%$ of ad libitum-fed controls, however, leptin treatment only partially advanced the occurrences of pubertal measurements compared to pair-fed controls, suggesting that leptin must not be a primary signal in initiation of puberty onset. Furthermore, intracerebroventricular (ICV) administration of leptin to food-restricted sheep (21) or rats (22) increases plasma LH, overcoming the effects of restricted nutrition. The consistent finding that both leptin and pulsatile $\mathrm{GnRH} / \mathrm{LH}$ secretion are reduced with energy restriction and that leptin replacement during periods of food restriction restores estrous cycle expression or LH secretion strongly supports leptin as a potential regulator of reproduction. Nonetheless, although leptin is clearly required for puberty onset and/ or estrous cyclicity, the current generally held view is that leptin is a permissive signal, rather than a trigger, for puberty onset.

\section{Insulin-like Growth Factor-1}


In addition to leptin, other factors likely also serve to link metabolic status with reproduction. IGF-1 is a hormone that has been associated with the regulation of puberty onset. The IGF-1 protein has a similar molecular structure to that of insulin and is known to play a significant role in growth and development. Circulating IGF-1 is largely dependent upon production by the liver and its synthesis is stimulated by GH, although local production of IGF-1 in many tissues is likely of high biological importance. Exogenous administration of IGF-1 was found to stimulate acute increases in pulsatile LH secretion in adult sheep (23). Moreover, various groups have demonstrated increases in IGF-1 during prepubertal development in rats, monkeys, and sheep (24-27). In immature female rodents, IGF-1 was found to stimulate GnRH release from the median eminence (ME) (28). Quantification of IGF-1 mRNA in the liver revealed increases in the content of IGF-1a and IGF-1b splice variants during the early proestrus phase of puberty; this change was accompanied by a rise in serum IGF-1 and gonadotropin levels, and IGF-1 receptor (IGF-1r) mRNA expression in the ME. Moreover, ICV administration of exogenous IGF1 stimulated LH secretion in both pre- and peripubertal female rats and advanced the occurrence of pubertal indices in prepubertal female rats (27). Studies performed by Suttie et al., 1991, revealed that treatment of prepubertal female lambs with exogenous GH increased plasma levels of IGF-1 and advanced the age at which animals produced high frequency LH pulses. However, it was also shown that GH declines just prior to puberty and that administration of GH to those lambs had no effect on the timing of puberty compared to vehicle-treated control animals (29). Although, these results indicate that GH may not necessarily provide direct cues for normal onset of puberty and sexual maturation in female lambs, the exact role of IGF-1 in the pubertal development of immature ewe- 
lambs remains to be fully elucidated. Additionally, it has been found IGF-1 receptors are widely distributed throughout the hypothalamus and pituitary in many species, suggesting that IGF-1 effects on puberty and reproduction are central rather than peripheral in this regard (30). This notion is supported by evidence of increased expression of IGF-1r mRNA in the ME during late prepubertal development, which is also thought to amplify GnRH release during the initiation of puberty in females (27).

\section{Insulin and Glucose}

Like IGF-1, insulin may be another factor that could potentially influence GnRH/LH secretion. In adult male monkeys, insulin secretion has been correlated with LH secretion. For example, 1 day of fasting resulted in suppression of circulating insulin and LH levels, and after re-feeding, these levels were quickly restored. However, insulin suppression by diazoxide, a potassium channel activator that inhibits pancreatic insulin secretion, had no effect on LH pulse frequency or amplitude (31). Moreover, acute, ICV injections of insulin had no effect on LH secretion in prepubertal female lambs (32), suggesting that insulin alone may not be an important metabolic signal that influences GnRH release. Glucose also has been implicated as an important signal, and experiments performed in rodents have implicated both the hypothalamus and hindbrain in sensing circulating glucose levels (33). ICV administration of 2-deoxy-D-glucose (2-DG), an antimetabolic analog of glucose, to female rodents significantly reduced the incidence of estrous cycles compared to animals that received an injection of glucose (34). Similarly, infusion of 2-DG into the fourth or lateral ventricle suppressed pulsatile secretion of LH in female sheep (35). In neither of these examples did peripheral administration of 2-DG, at an effective dose centrally, affect LH secretion, suggesting that central, but not systemic, 
glucose-sensing mechanisms can sufficiently detect insufficient metabolic fuels and suppress reproductive cyclicity if necessary. Moreover, destruction of catecholamine neurons (those producing norepinephrine and epinephrine) in the area postrema of the brainstem prevented the inhibition of estrous cycles by 2-DG in rats (36), but had no effect on normal estrous cycle expression, suggesting an adaptive response by the hindbrain to regulate "unnecessary" reproductive functioning and promote survival.

\section{Photoperiodic Control of Reproduction}

In addition to the energetic requirements for puberty onset, seasonality also is a prominent component that factors into the timing of puberty and reproduction in many animal species. Seasonally-breeding animals are influenced by photoperiod or other season-specific factors, such as nutrient availability, and successfully mate during one period of the year. These animal species are usually categorized as either long-day or shortday breeders. Long-day breeders, such as hamsters and horses, exhibit estrous cyclicity during the lengthening days of spring and summer and exhibit anestrus during the fall and winter months. Alternatively, short-day breeders, such as sheep and goats, exhibit estrous cyclicity during the shortening days of fall and winter but exhibit anestrus during the spring and summer months. The transition from the nonbreeding season to breeding season in adult ewes shares many characteristics that are similar to the onset of puberty in immature lambs. Seasonal anestrus is characterized by a reduction in pulsatile GnRH secretion, similar to that observed for prepubertal females (14). Furthermore, in order for breeding to begin, pulsatile GnRH secretion must reach adequate frequencies to sustain active stimulation of gonadotropes from the anterior pituitary and follicular development at the ovary. The sustained increase in GnRH pulse frequency and subsequent stimulation of 
gonadotropes will occur only when both internal cues, such as positive energy balance, and external cues, such as season, are sufficient for initiation and maintenance of a pregnancy. In the case of adult ewes, breeding during autumn is advantageous for both mothers and offspring. Because the gestational period in ewes is approximately 5 months, lambs are born during mid- to late-spring. This provides mother and offspring the opportunity for maximum nutritional benefits; the mother meets the energy demand of lactation, providing nourishment to her young throughout most of spring, and the offspring meets the energy demand of growth, preparing it for puberty and sexual receptivity in the following fall.

As mentioned above, sheep use photoperiod to time seasonal reproduction. Experiments performed as far back as the 1940's (37) revealed that modifying natural day-length with artificial photoperiod can reverse the timing of seasonal breeding and subsequent reproductive cycling. Moreover, photoperiodic control of reproduction is known to be mediated by melatonin, a hormone synthesized and secreted from the pineal gland. For instance, studies manipulating the plasma concentration of this hormone have demonstrated a similar effect to modifying natural day-length with artificial photoperiod on the timing of seasonal breeding (38). Incoming light stimulates retinal neurons that project to the suprachiasmatic nucleus ( $\mathrm{SCN}$ ) of the hypothalamus. This signal is then sent to the superior cervical ganglion (SCG), where it is converted into inhibition of neural activity. This results in lower release of norepinephrine at the pineal gland and, thus, melatonin secretion is decreased $(39,40)$. Thus, melatonin serves a critical time keeping function that is transduced into information that impacts $\mathrm{GnRH}$ release and seasonal breeding. The neural pathways that serve as a conduit for melatonin input to $\mathrm{GnRH}$ neurons are not completely known but may include hypothalamic neurons containing Kiss, 
$\mathrm{NKB}$, and DYN (or KNDy neurons) (41), as will be discussed later. In order for immature or mature females to advance into the breeding season, they must experience lengthening days before shortening days (38). This phenomenon has been extensively documented and reviewed throughout the past half-century. Of particular interest is the case of delayed puberty in ewe lambs born out of season: born in autumn rather than spring. A series of studies performed in the laboratory of Dr. Douglas Foster at the University of Michigan were aimed at elucidating the particular role of photoperiod in delayed onset of puberty in fall-born female lambs. He reported that spring-born lambs born under natural photoperiod, with no manipulation of light exposure, attained puberty at approximately 30 weeks of age during the following autumn. Conversely, fall-born lambs born under natural photoperiod did not reach puberty at 30 weeks of age, although they exhibited sufficient somatic development; rather, they attained puberty the autumn of the following year, at approximately 50 weeks of age. Moreover, by imposition of an artificial photoperiod mimicking a reversed annual photoperiod, fall-born lambs attained puberty the following spring at 30 weeks of age (39), suggesting that the inability of fall-born lambs to reach puberty at a normal age is primarily due to inappropriate photoperiod conditions at that time. Together, these data suggest that, at least in the more seasonal breeds of sheep, photoperiodic signals play a significant role in determining the timing of the onset of puberty.

\section{Determining the Onset of Puberty: Male and Female}

The onset of puberty has many definitions in both female and male sheep. Several criteria are used to determine the onset of puberty, which also facilitates classification of puberty as precocious or delayed if necessary. In females, the age at first estrus, the age at 
first ovulation, and the age at which a female can support pregnancy are all used as a means of determining the onset of puberty. Increased behavioral signs of sexual receptivity, which is relatively easy to determine, mark the age of first estrus. Detecting puberty onset by this method, however, may not accurately determine the true acquisition of puberty, as first estrus usually occurs after first ovulation because progesterone priming is needed for estrous behavior in ewes. Thus, a female lamb may have already experienced two or so "silent ovulations," resulting in estrous cycles with shortened or normal luteal phases, before displaying any outward signs of sexual receptivity. Nonetheless, because first ovulation is often difficult to determine and first estrus normally occurs within a few weeks of first ovulation, there is little practical relevance in distinguishing between the two in order to establish the timing of puberty. Another method that can help define puberty onset, which seems most applicable from a production standpoint, is determining whether an animal is old enough to support a pregnancy without self-detriment. Regardless of the method, puberty onset during the appropriate season in female lambs of Suffolk breed occurs at approximately 6 to 7 months of age. Like females, puberty in males occurs around 5 to 7 months of age and can be defined by several criteria; however, this classification is a bit more complex. Similar to signs of first estrus in females, males will display outward reproductive behavioral traits, such as mounting and erection. These signs, however, may occur long before the ability of rams to ejaculate and produce spermatozoa. The production of sperm takes approximately $50-70$ days, depending on species, and detection of threshold amounts of spermatozoa in the ejaculate provides a true classification of puberty because it defines a specific time when the male has the ability to reliably fertilize an ovum (42). However, properly determining the presence of spermatozoa in ejaculate and then 
validating that the ejaculate contains a threshold concentration of mature sperm can be an arduous task. Given the difficulties associated with sperm collection and evaluation, alternative means of determining the onset of puberty were sought, which also facilitate a more appropriate comparison in timing of puberty between the sexes. An applicable measurement of reproductive maturation similarly timed between female and male sheep is that of neuroendocrine development; more specifically, when the brain begins to produce high frequency $\mathrm{GnRH} / \mathrm{LH}$ secretion. This comparison will be investigated further in this review.

\section{Neural mechanisms involved in the onset of puberty of the prepubertal ewe lamb} Patterns of GnRH Secretion: Tonic versus Surge

To understand the regulation of neural mechanisms involved in timing the onset of puberty, it is imperative that the reader is able to distinguish between the tonic and surge centers of the hypothalamus. These areas control pulsatile (i.e. tonic) or surge-like GnRH output via negative or positive estrogen feedback acting at different anatomical sites; a surge center(s) that acts to produce a preovulatory surge of $\mathrm{GnRH} / \mathrm{LH}$ sufficient to induce ovulation, and a tonic center that acts to control the pulsatile secretion of $\mathrm{GnRH} / \mathrm{LH}$ pulses. Regulation of tonic GnRH/LH secretion by estradiol negative feedback has been identified as occurring in the more caudal aspects of the hypothalamus in sheep (41), rats (43), and primates (44). Conversely, control of surge-like GnRH secretion by estradiol positive feedback has been identified as occurring in the mediobasal hypothalamus (MBH) in sheep and the AVPV in rats. Coincidentally, these distinct anatomical regions (ARC/MBH and AVPV/POA) contain Kiss neurons that co-express estrogen-receptor- $\alpha$ (ER- $\alpha)(45-48)$, 
the receptor that mediates the effects of estrogen on GnRH output, signifying that the effects of estradiol are likely exerted directly on Kiss neurons in both areas. The population of Kiss neurons in the POA of sheep does not co-localize with NKB or DYN, whereas virtually all Kiss cells in the ARC contain NKB and DYN in this species (49). In the POA, approximately $90 \%$ of GnRH neurons contain Kiss receptor (kiss1r) and approximately $50 \%$ of Kiss neurons contain ER- $\alpha$ (50). Moreover, approximately $50-70 \%$ of GnRH neurons receive synaptic close contacts from KNDy neurons located in the ARC (50). The influence of estrogen feedback differs greatly between these two ostensibly unique populations of Kiss neurons. In adult female sheep and rats, exogenous administration of estrogen increases Kiss expression in the POA/AVPV and decreases Kiss expression in the ARC, while removal of estrogen feedback by ovariectomy decreases Kiss expression in the POA/AVPV and increases Kiss expression in the ARC (51). These data have led to the notion that Kiss neurons in the POA/AVPV interact with estrogen in a positive feedback manner to induce the preovulatory GnRH/LH surge, while Kiss (KNDy) neurons in the ARC interact with estrogen in a negative feedback manner (51).

\section{Surge Secretion of GnRH}

In the rat, the $\mathrm{GnRH} / \mathrm{LH}$ surge is controlled in the $\operatorname{AVPV}(52,53)$. In this region, high estrogen exerts stimulatory effects on ER- $\alpha$-containing Kiss cells afferent to GnRH neurons in the ME (54); Kiss stimulation of kiss1r-containing GnRH neurons in the ME results in a subsequent preovulatory $\mathrm{GnRH} / \mathrm{LH}$ surge. In rats, ER- $\alpha$-containing cells in the AVPV receive inputs from neurons in the suprachiasmatic nucleus $(\mathrm{SCN})$ representing a direct input for circadian influences on GnRH cells. This allows timing of the surge mechanism in the rat to the afternoon $(2 \mathrm{pm}-4 \mathrm{pm})$ of proestrus and resultant ovulation 
approximately 12 hours later. In sheep, recent evidence has suggested that the Kiss cell population in the ARC may work in conjunction with the POA population of Kiss neurons to elicit a preovulatory $\mathrm{GnRH} / \mathrm{LH}$ surge $(55,56)$. One theory suggests that in the $\mathrm{MBH}$, high levels of estrogen induce the surge via the ARC by acting directly to stimulate Kisscontaining KNDy neurons, which can then stimulate GnRH release via activation of GnRH cells or input to GnRH fibers in the ME (57) by way of axoaxonic regulation.

\section{Tonic Secretion of GnRH}

Theoretically, during pulse onset in sheep, increases in NKB stimulate KNDy neurons in an autocrine and/or paracrine manner to secrete Kiss, which acts directly to stimulate GnRH neurons, resulting in a subsequent rise in GnRH/LH (49). Although evidence for KNDy neuron involvement in pulse termination is not as clear as for pulse onset in ewes, many studies suggest that DYN release inhibits KNDy neuron activity to terminate GnRH pulses (41). An inhibitory role for DYN is suggested by the fact that this neuropeptide is an important mediator of progesterone negative feedback (58) and that DYN neurons co-localize with progesterone receptors to a high degree in adult ewes $(58,59)$. The control of tonic $\mathrm{GnRH} / \mathrm{LH}$ secretion by estrogen negative feedback in the $\mathrm{ARC}$ of rats is comparable to sheep and monkeys (60). In rodents, Kiss cells in the ARC directly stimulate GnRH neurons in the MBH by binding kiss1r (61), leading to the onset of a GnRH pulse and subsequent LH pulse. During pulse termination, recent evidence supports a role for DYN in mediating the negative feedback effects of estrogen (62). Moreover, progesterone-negative feedback via DYN has been implicated in pulse termination (63) suggesting that estrogen is not necessarily needed for the termination of GnRH/LH pulses during the luteal phase (59). 


\section{Reproductive-endocrine Axis as a Limiting Factor to Puberty Onset}

Although a large amount of research has been directed at understanding how the brain regulates puberty onset, the neural mechanisms involved in the timing of puberty are still not clearly understood. As previously discussed, in order to transition from a prepubertal to a pubertal state there must be an increase in the frequency of $\mathrm{GnRH} / \mathrm{LH}$ pulses to a point where follicular production of estradiol can be maintained at a high enough level to elicit the preovulatory $\mathrm{GnRH} / \mathrm{LH}$ surge and ovulation. Thus, insufficient function of any part of the reproductive endocrine axis could represent a limiting factor to puberty onset. Removal of estrogen negative feedback in prepubertal female sheep by ovariectomy results in high-frequency pulses of GnRH and corresponding LH pulses (2). Furthermore, hourly administration of exogenous GnRH to prepubertal female lambs induces LH pulses from the anterior pituitary (11). This suggests that hypothalamic GnRH neurons and pituitary gonadotropes are intact and able to competently communicate prior to puberty onset at a level sufficient to stimulate the final stages of follicular development and high levels of estradiol secretion. High, sustained levels of estradiol are the impetus for the preovulatory $\mathrm{GnRH} / \mathrm{LH}$ surge, thus it is possible that while estradiol levels are sufficiently elevated, the hypothalamic mechanisms underlying the surge are not capable of a response. However, hourly administration of LH to prepubertal females can elicit sufficient estrogen secretion from the ovaries to induce an LH surge and thus ovulation [1] and further work showed that female lambs could mount a GnRH/LH surge of a magnitude capable of causing ovulation by as early as 12 weeks of age (66). These data indicate that the preovulatory surge mechanism and subsequent ovarian responses are functional prior to the onset of puberty. Thus, the limiting factor for the initiation of puberty onset is not due 
to the maturation of anatomical or endocrine systems, rather it is the inability to produce high frequency pulses of GnRH/LH due to a high sensitivity to estrogen negative feedback. Early Theories of Estrogen Negative Feedback

The most straightforward mechanism would be for estradiol to directly inhibit GnRH neurons. However, GnRH neurons are devoid of ER- $\alpha$, the receptor whereby estrogen exerts negative effects on GnRH release $(47,67)$. This suggests that the neuroendocrine change in sensitivity to estradiol occurs through intermediary neurons. Early studies first tested whether the secretion of GnRH within the hypothalamus was possible prior to puberty onset by pharmacological stimulation of the $N$-methyl-D-aspartic acid (NMDA) receptor. These studies demonstrated that stimulation of NMDA receptors, a class of receptor for the ligands glutamate and aspartate, increased LH secretion prior to puberty onset in rats (68), rhesus monkeys (69), and sheep (70). Early theories also implicated endogenous opioids as mediators of estrogen negative feedback in prepubertal animals, given that they are known to inhibit GnRH secretion in adult sheep and opioid antagonist administration prior to puberty increases LH pulse frequency in lambs (71).

\section{Dietary Restriction and the Neuroendocrine Axis}

One approach that is commonly used to assess the potential involvement of specific neural pathways in linking metabolism with GnRH release is the imposition of feed restriction. One series of elegantly designed experiments by I'Anson et al., 2000, examined the effects of dietary-restriction on GnRH/LH secretion and puberty onset. They reported that immature female lambs in the growth-restricted group were hypogonadotropic and exhibited extended GnRH/LH inter-pulse intervals compared to a normal-growth group. Additionally, administration of sodium pentobarbital, a CNS inhibitor, resulted in reduced 
LH inter-pulse intervals and increased mean LH levels (72). Furthermore, Ebling et al., 1990, reported that hourly intravenous administration of NMDA increased LH secretion in hypogonadotropic, growth-restricted female lambs (70), suggesting that GnRH neurons are capable of high-frequency secretion during undernutrition. Together, these findings suggest that nutritionally growth-limited lambs are capable of LH secretion; however, inhibition of GnRH neurons by some upstream neuropeptide, influenced by a lack of sufficient nourishment, impedes normal functioning.

Several neuropeptides that are influenced by the effects of nutrition-induced growth retardation have been implicated in regulating GnRH secretion in lambs. Early work suggested that endogenous opioids might be potential mediators of metabolic changes in GnRH secretion. This is conceivable, given that injection of the anti- $\beta$-endorphin or antiDYN antibodies in the ARC of immature female rats increased serum LH levels (73) and that intravenous administration of naloxone, a non-selective opioid antagonist, increased LH secretion and LH pulse frequency in 12-week old lambs (71). However, evidence of endogenous opioid involvement in relaying metabolic signals is limited to fasted rodents $(74,75)$ and there is little to no evidence of endogenous opioid activity associated with food-restriction presented in lambs. Some authors suggest, though, that inhibiting endogenous opioid pathways may be activated during periods of reduced nutrition and energy but are secondary to other overriding pathways, such as that of neuropeptide $\mathrm{Y}$ (NPY) (76).

\section{Neuropeptide $Y$}

NPY is a 36-amino acid peptide that is abundantly distributed throughout the central and peripheral nervous systems and is highly expressed in the ARC of rats (77), 
primates (78), and sheep (79). Additionally, NPY has been implicated in the regulation of food intake and energy expenditure (80), as well as inhibition of LH secretion $(80,81)$. Hypothalamic NPY neurons are known to be responsive to metabolic signals as evidenced by co-localization with leptin receptors, and changes in NPY expression are often explained by changes in systemic leptin concentrations. A large number of NPY neurons in the ARC co-express leptin receptors in rats (82) and mice (83), and furthermore, colocalization of NPY and leptin receptor in the ARC is clearly evident in nonhuman primates as evidenced by in situ hybridization studies (84). Additionally, leptin receptor expression was found in the anterior pituitary and ARC in sheep (85). Moreover, in the ARC, leptin receptor expression was found to be differentially expressed in normal versus feedrestricted animals (85). Because NPY is able to stimulate food intake (86) and administration of exogenous leptin inhibits both NPY gene expression and secretion (87), it is highly likely that NPY is a potential mediator of leptin signaling in the CNS (82) and a potent stimulator of feeding behavior. In prepubertal animals, when adipocyte content and circulating leptin concentrations are low, NPY expression is high and may exert negative effects on GnRH, and subsequently LH, output. As time progresses and animals grow, circulating levels of leptin may reach a sufficient amount to inhibit or significantly decrease NPY secretion and thereby increase secretion of GnRH. NPY neurons also coexpress agouti-related peptide (AgRP), a potent and long-lasting stimulator of appetite and regulator of energy balance (88). Very little evidence has supported a role for AgRP in reproduction in sheep; however, AgRP deficiency has been reported to advance puberty in female rodents, implicating AgRP as an inhibitory influence on reproduction (89). Additionally, like NPY, food-restriction profoundly increases the expression of AgRP in 
the ARC of sheep (90), and AgRP acts as an antagonist of the melanocortin receptors, MC3-R and MC4-R (88). These receptors are directly associated with energy balance and metabolism and are activated by melanocyte-stimulating hormone ( $\alpha-\mathrm{MSH})(88)$, an important factor in satiety found to deter food intake. $\alpha$-MSH is one of several peptides derived from the proopiomelanocortin (POMC) gene and expression of POMC mRNA is reported to decrease with fasting in rodents (91). Additionally, ARC neurons containing products of POMC genes have also been found to contain leptin receptors in this region (76) and have been shown to make direct synaptic contact on GnRH and Kiss neurons in the POA in mice (92) and rats (93). As previously mentioned, both AgRP and $\alpha$-MSH interact with MCR-4, through which AgRP acts to stimulate, and $\alpha$-MSH acts to inhibit food intake (94). During food restriction, increases in AgRP expression are considered an adaption meant to disrupt $\alpha$-MSH input, thus stimulating food intake and altering basal metabolic rate (90). As $\alpha$-MSH has also been implicated in stimulating LH release in sheep (95), antagonism of melanocortin receptors by AgRP, thus reducing $\alpha$-MSH input, supports earlier data suggesting an inhibitory role of AgRP on GnRH/LH secretion.

\section{Kisspeptin-containing Neurons}

Kiss-containing neurons - more specifically a neuronal subpopulation located in the ARC co-expressing Kiss, NKB, and DYN $(41,96)$, given the acronym KNDy neurons - have also been shown to play a role in the regulation of GnRH secretion, and various studies have implicated Kiss as a major factor in regulating the onset of puberty, which will be thoroughly discussed in later sections. Kiss, transcribed from the KISS1 gene, is found in fairly discrete regions throughout the midbrain, namely the ARC and the rostral periventricular region of the third ventricle within the hypothalamus, and a small 
population in the POA (49). Additionally, Kiss neurons interact with both NPY and POMC neurons, two primary targets of leptin (97), and the ARC population contains receptors for both leptin (98) and insulin (99). Much of the data, however, has been inconsistent with regard to the degree of leptin receptor expression: i.e., reports of Kiss neurons expressing leptin receptor range from approximately $6 \%(98)$ to $40 \%$ (100). Moreover, ablation of leptin receptors from Kiss neurons prior to puberty had no effect on the onset of puberty or reproductive cyclicity in immature female mice (101); this result dampened the notion for a possible role of leptin-Kiss signaling during the onset of puberty, at least in rodents. Ablation of insulin receptors from Kiss neurons in immature female mice, however, resulted in delayed puberty, but normal fertility thereafter, suggesting that insulin sensing by Kiss neurons may play a role in initiating the onset of puberty (99). Intriguingly, food deprivation of immature female and male rodents resulted in a reduction of hypothalamic KISSI mRNA (102), which is similar to the response in adult female sheep (97). Moreover, administration of leptin to female sheep fed to exhibit reduced body fat partially restored KISS1 mRNA when compared to normally fed animals (97). That response not only reinforced a positive relationship between leptin and Kiss in sheep, but also suggested some evidence of species differences. Although these data are intriguing, the exact nature of these interactions in various species requires further investigation.

\section{KNDy neurons and the initiation of puberty in the prepubertal ewe lamb}

\section{Kisspeptin}

Kiss, belonging to the RF amide family, first received attention as a key regulator of puberty onset when reports of mutations in the receptor, Kiss1r, or the peptide itself 
interdicted pubertal development and led to hypogonadotropic hypogonadism in humans (103-105). Results from gene deletion studies for Kiss and Kiss1r, a G-protein coupled receptor, in mice corroborated these earlier findings as they reported absent and/or delayed pubertal onset and sexual maturation, coupled with low concentrations of gonadotropins (106). Importantly, the gonads of the mice in these studies were responsive to administration of exogenous gonadotropins, and treatment with GnRH stimulated LH release (106). Furthermore, administration of Kiss stimulated GnRH and/or LH secretion prior to puberty in many species: rodents (107), primates (108), sheep (109), and cattle (110). Navarro et al., 2004, reported that central administration of Kiss to immature female rats increased plasma LH levels and advanced vaginal opening, a marker for pubertal onset (111). In primates, after GnRH priming of the pituitary gland, Kiss administration elicited GnRH-dependent LH secretion in gonadectomized prepubertal males (112). Moreover, hourly intravenous injections of Kiss result in both pulse-like secretion of LH, within minutes of the first injection, and surge-like secretion of LH, within hours, after the start of treatment in prepubertal ewe lambs (113). Additional studies imply that Kiss may initiate the emergence of reproductive function at puberty, as an increase in Kiss mRNA expression is noted just prior to puberty onset in rats (114) and monkeys (60). GnRH neurons in both mice and sheep have also been shown to co-express Kiss1r, implying that GnRH secretion is directly regulated by Kiss. Approximately $90 \%$ of GnRH neurons express KISS1R (previously known as GPR54) mRNA in both immature and mature mice (115). Moreover, the expression of KISSIR mRNA in GnRH neurons dramatically increases in the AVPV at sexual maturation (115). Correspondingly, Kiss cell numbers increased over postnatal development and were at adult-like levels at the time of puberty 
onset in the AVPV of female mice (116). Immunocytochemical studies also have demonstrated that KNDy neurons do not co-express Kiss1r, ruling out any autocrine or paracrine communication via Kiss (55). Moreover, ARC KISS1 mRNA increases after ovariectomy and is inhibited after estrogen replacement in adult ewes (117) and rats (118). Additionally, Kiss-immunoreactive cells in the ARC increase after ovariectomy in immature lambs and Kiss cell numbers are higher in postpubertal, compared to prepubertal, ovary-intact ewes (119), suggesting that sex steroids, namely estrogen, regulate Kiss expression. These data further support the possibility that this system (Kiss/GnRH/LH) is fully functional prior to puberty; however, it is inhibited by estrogen negative feedback.

\section{Neurokinin B}

As previously mentioned, Kiss neurons in the ARC also co-express NKB (46). $\mathrm{NKB}$ is a member of the tachykinin family, a large group of excitatory neuropeptides found in nearly all species (120). Tachykinins act through three known tachykinin receptors: NK1R, NK2R, NK3R. All three receptor subtypes are 7 membrane domain receptors that activate the phosphatidylinositol transduction pathway. While these receptors are not exclusively specific for any tachykinin (substance $\mathrm{P}$, neurokinin A, or NKB), each receptor has differing affinities for each tachykinin: NK1R preferentially binds to substance P, NK2R to neurokinin A, and NK3R to NKB (121). NKB was first associated with reproduction when reports emerged detailing hypertrophy of NKB-containing neurons in the ARC of postmenopausal women, a presumed result of increased LH secretion due to a decrease in ovarian estrogen negative feedback (122). Since then, studies in sheep have shown that administration of an NK3R agonist, senktide, into the retrochiasmatic area (RCh), POA, or ARC $(115,123,124)$ stimulated GnRH/LH secretion. Conversely, central 
administration of senktide to ovariectomized, estrogen-treated rats (125) and mice (107) inhibited LH secretion, which raises the potential for species differences. Recently, NKB has been implicated in puberty. Humans with loss of function mutations in the TAC3 or $T A C R 3$, genes that encode the NKB peptide or NK3R, respectively, displayed an absence of puberty and severe congenital gonadotropin deficiency (121). Moreover, recent work in rodents demonstrated that intraperitoneal administration of the NK3R agonist senktide advances puberty onset in female rats (126), and chronic central administration of SB222200, a selective NK3R antagonist, delayed puberty in female rats (127). Consistent with these findings, intravenous injection of senktide in prepubertal male primates elicited LH secretion (128). Additionally, Nestor et al., 2012, demonstrated that single injections of senktide increased LH secretion in prepubertal female sheep, a result that was blocked by administration of a GnRH receptor antagonist, suggesting a hypothalamic site of stimulation (129). Although NK3R activation has been shown to stimulate LH secretion in prepubertal animals, whether or not NKB plays an active role in timing the initiation of puberty onset in females is still unknown. Interestingly, GnRH neurons do not contain NK3R, while KNDy neurons do $(49,124)$. This suggests that NKB may communicate in an autocrine and/or paracrine manner amongst KNDy cells, rather that acting directly on GnRH neurons; however, further investigation is need in order to determine if that is so.

\section{Dynorphin}

In the ARC, a large fraction of Kiss neurons also contain DYN (49). DYN is an opioid peptide derived from its prodynorphin protein precursor and selectively binds the $\mathrm{\kappa}$ opioid receptor (к-OR). Early literature implicated endogenous opioids, such as DYN, as potential mediators of estrogenic inhibition of $\mathrm{GnRH}$ release $(63,70,71,73,130)$. In 
immature female rats, injection of anti- $\beta$-endorphin and anti-DYN antibodies in the ARC of the MBH increased serum LH levels (73). Additionally, ICV infusion of naloxone, a non-selective opioid antagonist, or norbinaltorphimine (nor-BNI), a highly specific $\kappa-\mathrm{OR}$ antagonist, increased LH pulse frequency in early gestating rats (63). Intravenous administration of a bolus of naloxone to ovariectomized and estrogen treated adult sheep during the breeding season resulted in an increase in LH pulse frequency; however, naloxone treatment to the same animals during the anestrous season did not have any effect, suggesting that opioid involvement in the inhibition of GnRH secretion is not the same between breeding and anestrous seasons (130). Similarly, intravenous naloxone administration to ovary-intact or ovariectomized and estrogen treated 12-week old prepubertal female lambs resulted in increases in LH secretion and LH pulse frequency (71). More recent studies demonstrated that DYN mediates progesterone negative feedback in the adult female sheep because administration of nor-BNI in the MBH produced an immediate pulse of LH and increased LH pulse frequency in luteal phase animals (59). Furthermore, DYN expression was increased in the presence of progesterone, as seen in luteal phase compared to ovariectomized adult ewes (59). Very little work, however, has been done addressing the potential involvement of DYN in puberty. Nakahara et al., 2013, demonstrated that administration of nor-BNI advanced puberty indices in female rats (126). In that study, immature female rats were implanted with nor-BNI-containing osmotic minipumps in the intraperitoneal cavity designed to chronically administer that pharmacological agent. They monitored vaginal opening and first estrus, known markers of puberty in rodents, and found that vaginal opening tended to be earlier and estrous cyclicity occurred significantly earlier in the nor-BNI-treated group compared to controls. 
Additionally, LH pulse frequency was increased in the nor-BNI-treated group compared to the vehicle-treated group (126). Together, these data suggest that DYN-k-OR signaling may contribute to the suppression of $\mathrm{GnRH} / \mathrm{LH}$ secretion in prepubertal animals and that the tempering of DYN-k-OR signaling may initiate puberty onset in premature female rats. As previously discussed, endogenous opioid peptides have been implicated in inhibiting LH secretion in prepubertal lambs; however, essentially no work has been done addressing the role of DYN in regulating prepubertal GnRH/LH secretion in this species.

\section{KNDy Neurons and the Initiation of Puberty in the Prepubertal Ewe Lamb}

The onset of puberty is strongly governed by a decrease in hypothalamic sensitivity to estrogen negative feedback $(2,64,131)$. In immature animals, the hypothalamus is highly sensitive to low levels of estradiol, inhibiting GnRH secretion from the hypothalamus and thus suppressing LH secretion from the adenohypophysis (4). Recent evidence has implicated KNDy neurons in the ARC of the hypothalamus as likely candidates mediating such interneuronal communication. As detailed above, KNDy neurons co-express NK3R, $\kappa-\mathrm{OR}$, and ER- $\alpha$, but do not co-express Kiss1r; GnRH neurons co-express both Kiss1r and $\kappa-\mathrm{OR}$, but do not co-express NK3R and ER- $\alpha$. Moreover, NK3R is found in multiple locations within the hypothalamus, such as the ARC, RCh, and the POA. A current model of how this system might operate during the onset of puberty is as follows. In prepubertal lambs, GnRH/LH secretion is low due to heightened sensitivity to estrogen negative feedback, which may be mediated, at least in part, by DYN. DYN may act to inhibit KNDy neurons in an autocrine and/or paracrine manner or directly inhibit GnRH neurons, given both neural populations have $\kappa-\mathrm{OR}$. As the animal continues to grow and mature and photoperiod becomes permissive to reproduction, sensitivity to estrogen negative feedback 
decreases, thus reducing inhibitory input from DYN. As a result, Kiss and NKB synthesis and secretion is increased, and these neuropeptides begin to stimulate GnRH secretion. Eventually, GnRH pulse frequency is increased, resulting in a subsequent increase in the number of LH pulses, ultimately leading to initial ovulation, acquisition of puberty, and normal reproductive functioning. An extensive body of evidence demonstrates that KNDy neurons are actively involved and regulate the timing of puberty. Moreover, multiple studies provide evidence that KNDy neurons can integrate numerous external and internal cues that regulate the onset of puberty. However, what constitutes the prepubertal neural brake on puberty is not clear and, in particular, the role that DYN may play in this regard. That is the subject of this thesis.

Agricultural and Clinical Applications of Research in Reproductive Neuroendocrinology

Investigation within the field of reproductive biology explores novel and important aspects of reproduction that affect both agricultural and clinical applications. Successful completion of studies pertaining to reproductive neuroendocrinology elucidates neural mechanisms involved in regulating the onset of puberty and provides important insight into the inner-workings of the hypothalamic-pituitary axis. From an agricultural standpoint, increasing the efficiency of food production is a major goal. One approach to refining production methods is improving the reproductive efficiency of domestic farm animals. In order to do so, producers have employed various forms of assisted reproductive technologies: in vitro fertilization, intrauterine insemination, and cryopreservation. Research focused on the hypothalamic-pituitary-gonadal axis is rich in information beneficial to improving these forms of advanced reproductive technologies. Furthermore, not only does this work have importance and potential impact on farm animal production, 
it may have application to human reproduction. It may provide insight into potential mechanisms involved in the growing epidemic of precious puberty in girls. Over the last couple of decades, young women have been maturing at an early age, and the number of documented cases of precocious puberty has increased dramatically (132). The cause of many cases of precocious puberty still remains unclear. However, the nutritional status of these patients is thought to be a prominent factor in the early occurrence of sexual maturity (133). Moreover, in addition to nutrition, or more specifically over-nutrition, genetics and environmental factors are contributing factors in the expression of precocious puberty (132). Precocious puberty not only leads to a possible heightened social stigma, but also to increased risk of other health-related issues, such as early bone maturation, which can stunt growth at an early age. Although some treatments have been identified, i.e., the use of continuous GnRH agonists, more work in this field is needed to better understand, treat, and prevent this emergent concern.

\section{Hypotheses}

The hypotheses forwarded by this thesis aim to elucidate the role of KNDy neurons and, more specifically Kiss and DYN, in ovine sexual maturation. The literature presented herein implicates Kiss as stimulatory and DYN as inhibitory to GnRH/LH secretion in prepubertal lambs. Thus, it was hypothesized that estrogen is inhibitory to Kiss and stimulatory to DYN in a prepubertal state. Moreover, it was hypothesized that blocking $\kappa$ ORs will eliminate the inhibitory effects of DYN on pulsatile LH secretion in prepubertal animals. 


\section{CHAPTER II: MATERIALS AND METHODS}

\section{$\underline{\text { Animals }}$}

Suffolk Lambs (6 - 10 months old) were housed and studied in the West Virginia University (WVU) Food Animal Research Facility (FARF). Animals received an alfalfa pellet food ration and had free access to water and mineral supplement. Additionally, sensory stimulation objects were provided for enrichment. Indoor lighting simulated the natural changes in day length. Prior to arrival at the FARF, animals were housed outdoors in open barn. All procedures were approved by the West Virginia University Animal Care and Use Committee and followed National Institutes of Health guidelines for use of animals in research.

\section{$\underline{\text { General Methods }}$}

Ovariectomies and neurosurgeries were performed under sterile conditions. Ovaries were removed via a midventral incision using sterile techniques after animals had been anesthetized with $1-3 \%$ isoflurane in oxygen gas. For cannulation of the lateral ventricle, animals were first anesthetized by intravenous injection of ketamine $(7 \mathrm{mg} / \mathrm{kg})$ and midazolam $(0.3 \mathrm{mg} / \mathrm{kg})$, and then maintained on $1-3 \%$ isoflurane. The head was positioned appropriately in a stereotaxic instrument (Kopf Instruments, Tujunga, CA) and a small hole $(0.5 \mathrm{~cm}$ in diameter) was drilled in the skull $5 \mathrm{~mm}$ anterior and $4 \mathrm{~mm}$ lateral to bregma. The dura was exposed, cauterized, and a 16 gauge needle (with a reservoir containing sterile water) was lowered until water flowed into the ventricle. Radio-opaque dye (1.5 mL Iohexol, MXR SourceOne Healthcare, San Deigo, CA) was injected into the ventricle, a lateral X-ray was taken, and the dorsal-ventral postion of the needle was 
adjusted to be centered in the ventricle. The needle was plugged, cemented in place in the skull, and covered with a cap using dental acrylic. The skin was sutured around the dental acrylic.

Estrogen replacement was accomplished in the form of a 1-cm long SILASTIC implant (Dow Corning, Corp., Midland, MI) inserted subcutaneously in the axillary region at the time of ovariectomy and left in place for the duration of the experiment. Progesterone replacement was accomplished by insertion of one or two intravaginal progesterone Controlled Internal Drug Release (CIDR) devices at least 4 days before treatments.

\section{$\underline{\text { Tissue collection }}$}

Tissue was collected as described previously (129). Briefly, all sheep were heparinized (20,000 U) and killed using an intravenous (IV) overdose of sodium pentobarbital (Euthasol; Webster Veterinary, Devens, MA). Heads were removed and perfused via the carotid arteries with four liters of $4 \%$ paraformaldehyde in $0.1 \mathrm{M}$ phosphate buffer $(\mathrm{PB})(\mathrm{pH} 7.4)$ containing $0.1 \%$ sodium nitrite. Blocks of tissue containing the hypothalamus and POA were then removed and stored in 4\% paraformaldehyde for 24 $\mathrm{h}$ at $4 \mathrm{C}$ and transferred to $20 \%$ sucrose until sectioned. Frozen coronal sections $(50 \mu \mathrm{m})$ were cut with a freezing microtome and stored in cryopreservative until the time of immunocytochemical staining.

\section{Experiments}

Experiment 1: Will changes in immunopositive Kiss/DYN cell numbers reflect changes in estrogen negative feedback?

Ewe lambs (March-born) were assessed at three different time points: prepubertal (6 months), peripubertal (7 months), and predicted postpubertal (8 months). Within each 
age group, lambs were randomly divided into three treatment groups: ovary-intact $(n=5)$, ovariectomized $(n=5)$, and ovariectomized with estrogen replacement $(n=5)$. Ovary-intact animals did not undergo surgery or receive estrogen implants. Two weeks post-surgery, blood samples were collected by jugular venipuncture into heparinized tubes every 12 minutes for $4 \mathrm{~h}$ and the blood plasma was stored at $-20 \mathrm{C}$. Hypothalamic tissue was collected immediately after the final blood sample was taken.

Experiment 2: Will administration of a k-opioid receptor antagonist into the lateral ventricle stimulate LH secretion?

A preliminary experiment was performed in adult ewes to test the effectiveness on LH secretion of a dose of nor-BNI that was selected for use in lambs based on data in adult goats (134). Adult ovariectomized ewes $(\mathrm{n}=4)$ were pretreated with a $1 \mathrm{~cm}$ long estrogen implant and 2 CIDRs to suppress LH section and because nor-BNI is known to increase LH secretion in the presence of progesterone (59). All animals were infused ICV with artificial spinal fluid (aCSF) for $3 \mathrm{~h}(300 \mu \mathrm{l} / \mathrm{h})$ followed by infusion ICV with $60 \mathrm{nmol} / \mathrm{h}$ of nor-BNI for $3 \mathrm{~h}(300 \mu \mathrm{l} / \mathrm{h})$. Throughout, blood samples were collected every 12 minutes via jugular catheters, placed into heparinized tubes, and plasma was stored at $-20 \mathrm{C}$. Because this dose of nor-BNI increased LH pulse frequency from $1 \pm 0.4$ pulses $/ 3 \mathrm{~h}$ to 2.3 \pm 0.6 pulses $/ 3 \mathrm{~h}$, it was used in subsequent experiments.

In experiment $2 \mathrm{~A}$, prepubertal ewes $(6$ months $)(\mathrm{n}=6)$ were ovariectomized, implanted with a $1-\mathrm{cm}$ estrogen implant, and a guide cannula was placed in one lateral ventricle. At least 14 days after surgery, ewe lambs were assigned randomly to receive either aCSF, as a control, or nor-BNI. Animals were infused ICV with aCSF for $3 \mathrm{~h}$ or with $60 \mathrm{nmol} / \mathrm{h}$ of nor-BNI for $3 \mathrm{~h}$. Blood samples were collected at 12 -minute intervals for 36 
minutes prior to and for the entire infusion period by jugular catheter, then placed in heparinized tubes; plasma was stored in $-20 \mathrm{C}$. One week later, the process was repeated using a cross-over design so that each lamb received both treatments.

In experiment $2 \mathrm{~B}$, the effects of nor-BNI in the presence of progesterone was tested as a positive control for experiment $2 \mathrm{~A}$. Immediately after the last blood sample was collected in experiment 2A, one CIDR was inserted into each lamb. A week later, ewe lambs underwent a treatment paradigm similar to that described for experiment $2 \mathrm{~A}$ with the following exception; animals were infused ICV with aCSF or with $60 \mathrm{nmol} / \mathrm{h}$ of norBNI for $4 \mathrm{~h}$ instead of $3 \mathrm{~h}$ because pulse frequency was expected to be lower than in experiment $2 \mathrm{~A}$ due to the inhibitory effects of progesterone. Blood samples were collected at 12-minute intervals for 36 minutes prior to and for the entire $4 \mathrm{~h}$ infusion period by jugular catheter. Blood was placed in heparinized tubes and plasma was stored at $-20 \mathrm{C}$. All animals received both treatments in a cross-over design with treatments separated by 1 day. CIDRs were removed at the end of this experiment, but estrogen implants were left in place in preparation for experiment $2 \mathrm{C}$.

Experiment $2 \mathrm{C}$ was performed in these same estrogen-treated ovariectomized animals when they were considered to be of a postpubertal age, approximately $7-8$ months of age. Ewe lambs were assigned randomly to receive either aCSF, as a control, or norBNI using a treatment approach similar to that described for experiment $2 \mathrm{~B}$ with treatments separated by 2 days.

\section{$\underline{\text { Single-label Immunocytochemistry for Kiss or DYN }}$}

Prior to immunostaining, three sections of the middle to caudal ARC from each animal (pre-/peri-/postpubertal for Kiss and DYN and adult luteal phase for DYN) were 
selected. On day 1 , sections were washed $4 \times 5 \min$ in $0.1 \mathrm{M}$ phosphate-buffered saline (PBS) and stored overnight at 4 C. On day 2 , sections were washed $4 \times 5$ min in PBS then placed in $10 \% \mathrm{H}_{2} \mathrm{O}_{2}$ for 10 min followed by $4 \times 5$-min washes in PBS. Tissue was then incubated for $1 \mathrm{~h}$ with $0.4 \%$ Triton X (Sigma-Aldrich, St. Louis, MO) in 20\% normal goat serum for Kiss or $4 \%$ normal goat serum for DYN, both made in PBS. Kiss and DYN neurons were identified using primary antibodies for Kiss (gift from A. Caraty) and DYN (Phoenix Pharmaceuticals, Inc., Burlingame, CA) that have been validated for use in sheep $(46,135)$. Tissue sections were incubated with 1:50,000 Kiss antiserum raised in rabbit or 1:10,000 DYN antiserum raised in rabbit for $18 \mathrm{~h}$ at room temperature. On $\mathrm{d} 3$, biotinylated goat antirabbit antibody (Vector Laboratories, Burlingame, CA) at 1:500 and Vectastain $\mathrm{ABC}$-elite (Vector Laboratories) at 1:500 were applied sequentially for $1 \mathrm{~h}$ each with $4 \times$ 5-min washes of PBS between incubations. Sections were then placed in a 3,3'diaminobenzidine tetrahydrochloride (DAB) solution (10 mg of DAB [Sigma-Aldrich, St. Louis, $\mathrm{MO}$ ] in $50 \mathrm{~mL}$ of $\mathrm{PB}$ with $20 \mu \mathrm{l}$ of $30 \% \mathrm{H}_{2} \mathrm{O}_{2}$ added just before incubation) for 10 min. After $3 \times 5$-min washes in PB, sections were mounted on Superfrost/Plus microscope slides (Fisher Scientific, Pittsburgh, PA), dehydrated using a series of increasing alcohol baths, and coverslipped using DPX Mounting Medium (Electron Microscopy Sciences, Hatfield, PA).

\section{$\underline{\text { Data analysis }}$}

Immunocytochemistry

For each antigen staining, cell bodies, identified by cells containing a brown cytoplasmic staining, were counted using an Olympus AZ70 transmitted light microscope (Center Valley, PA) from sections of middle to caudal ARC (three sections/animal), and 
mean cell numbers/section for each group were averaged, because there was no difference in cell numbers between the middle and caudal ARC.

Assays

Concentrations of LH were measured in duplicate with a RIA using 100-200 $\mu$ of plasma and reagents provided by the National Hormone and Peptide Program (Torrance, $\mathrm{CA}$ ) as previously described (136). Assay sensitivity averaged $0.07 \mathrm{ng} /$ tube (NIH S24) with intra- and interassay coefficients of variation being 12.7 and $18.2 \%$, respectively.

\section{Statistics}

For experiments examining Kiss cell numbers during pubertal development, treatment group means for the three groups were compared by one-way analysis of variance with steroid treatment as a factor. Values of LH were compared by repeated measures analysis of variance. Mean LH and LH pulse amplitude were analyzed by one-way ANOVA with repeated measures. Wilcoxon Mann-Whitney or Friedman's two-way ANOVA test were used to compare LH pulse frequency. Differences were considered to be significant at $P<0.05$. 


\section{CHAPTER III: RESULTS}

\section{Experiment 1: Will changes in immunopositive Kiss/ DYN cell numbers reflect changes in estrogen negative feedback?}

\section{LH Data}

As expected, Mean LH and LH pulse frequency were significantly higher in ovariectomized (OVX) animals compared to ovary-intact and ovariectomized with estrogen replacement $(\mathrm{OVX}+\mathrm{E})$ groups in the prepubertal age group (Fig. 1, Fig. 2A). In peripubertal animals, LH pulse frequency was significantly higher in OVX animals compared to ovary-intact and $\mathrm{OVX}+\mathrm{E}$ groups and LH pulse frequency was significantly higher in $\mathrm{OVX}+\mathrm{E}$ versus ovary-intact animals. Moreover, mean LH levels were significantly increased by OVX compared to animals in the ovary-intact and OVX $+\mathrm{E}$ groups (Fig. 2B). In postpubertal animals, LH pulse frequency was significantly higher in animals that were OVX compared to animals that were OVX+E, but not ovary-intact animals. Mean LH was significantly increased in OVX animals compared to the other two groups (Fig. 2C). 

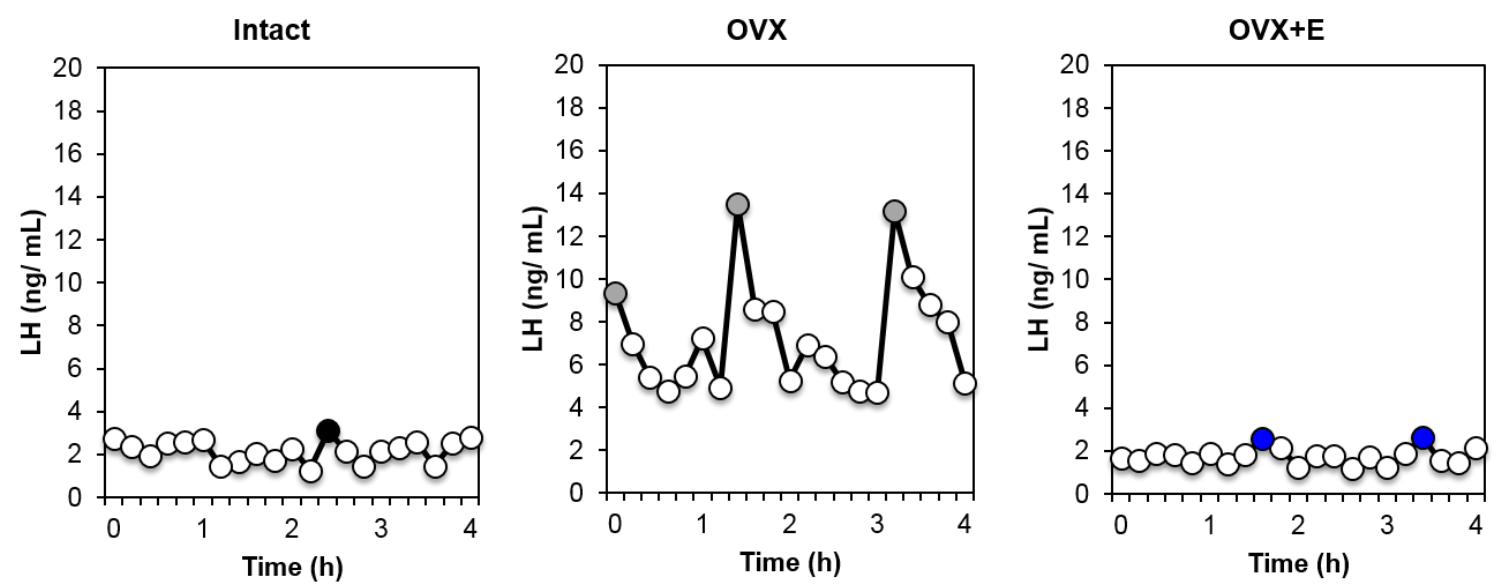

Figure 1: Representative LH pulse profiles for individual prepubertal females that were either ovary-intact, OVX or OVX an OVX+E (pulses signified by black closed circle (intact), grey closed circle (OVX), and blue closed circle (OVX+E). 
A. Prepubertal

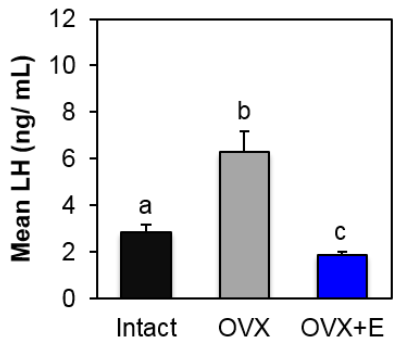

B. Peripubertal

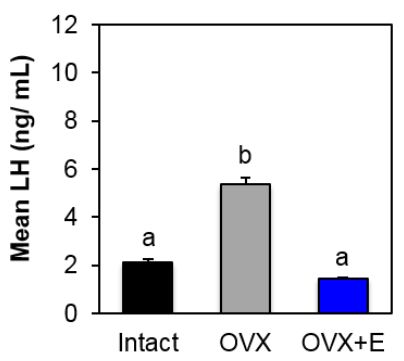

C. Postpubertal

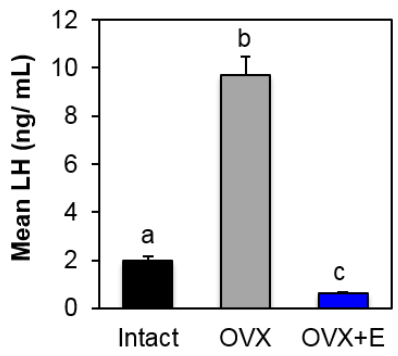

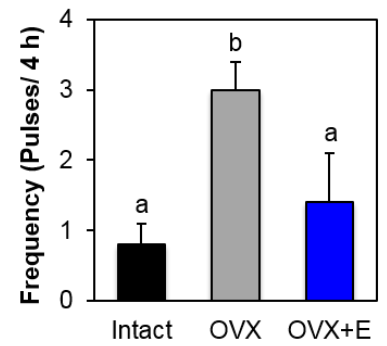
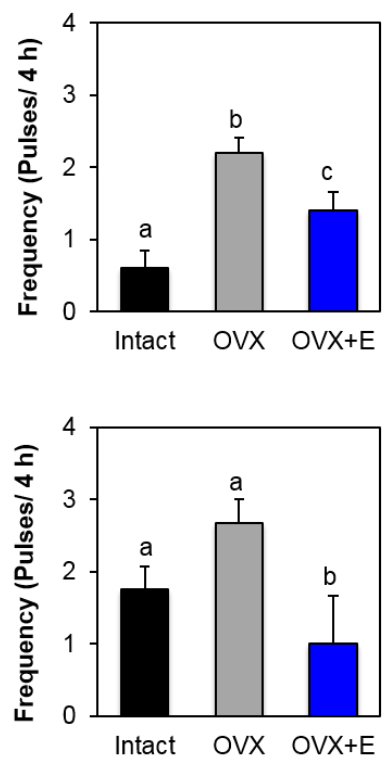

Figure 2: Mean \pm SEM for mean LH and number of LH pulses for prepubertal (A), peripubertal (B), and postpubertal (C) ewe lambs that were either ovary-intact $(n=4)$, OVX $(n=5)$, or OVX $+E(n=5)$. Differing letters indicate significant differences $(p<0.05)$. LH pulse amplitude is not shown because the low number of pulses in the intact or OVX+E group precluded comparisons amongst treatment groups.

As hypothesized, Kiss-immunoreactive cells in the ARC were increased by OVX compared to either ovary-intact or $\mathrm{OVX}+\mathrm{E}$ groups in prepubertal animals (Fig. 3). Additionally, Kiss-immunoreactive cells were significantly higher in ovary-intact compared to $\mathrm{OVX}+\mathrm{E}$ animals. In peripubertal animals, Kiss-immunoreactive cells were increased by OVX compared to either ovary-intact or $\mathrm{OVX}+\mathrm{E}$ groups in prepubertal animals, but the latter two groups were not significantly different (Fig. 3). In postpubertal 
animals, Kiss-immunoreactive cells were slightly, but significantly, increased by OVX compared to either ovary-intact or OVX+E groups (Fig. 3).

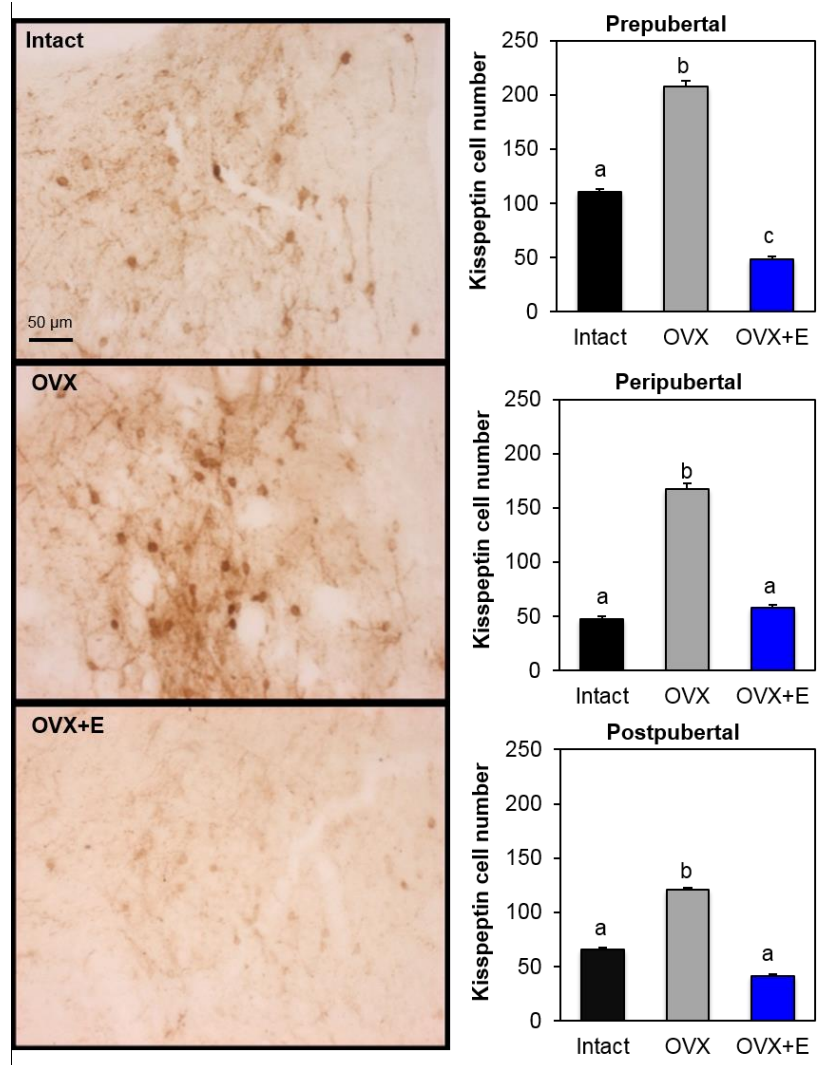

Figure 3. Representative photomicrographs of Kiss (left) within the ARC from prepubertal lambs that were ovary-intact Intact, OVX, or OVX+E. Kiss cell numbers in the ARC of female lambs from the three treatment groups at three ages (right). Differing subscripts within age denote significant difference $(\mathrm{p}<0.05)$.

Contrary to the hypothesis that DYN expression would be increased by estrogen in prepubertal females and decrease during pubertal maturation, very few DYNimmunopositive cells were found in the ARC of any treatment group within any age, even though they were readily evident in control hypothalamic tissue concurrently assessed from adult ewes $(\mathrm{n}=3)$ in the luteal phase of the estrous cycle (Fig. 4). 


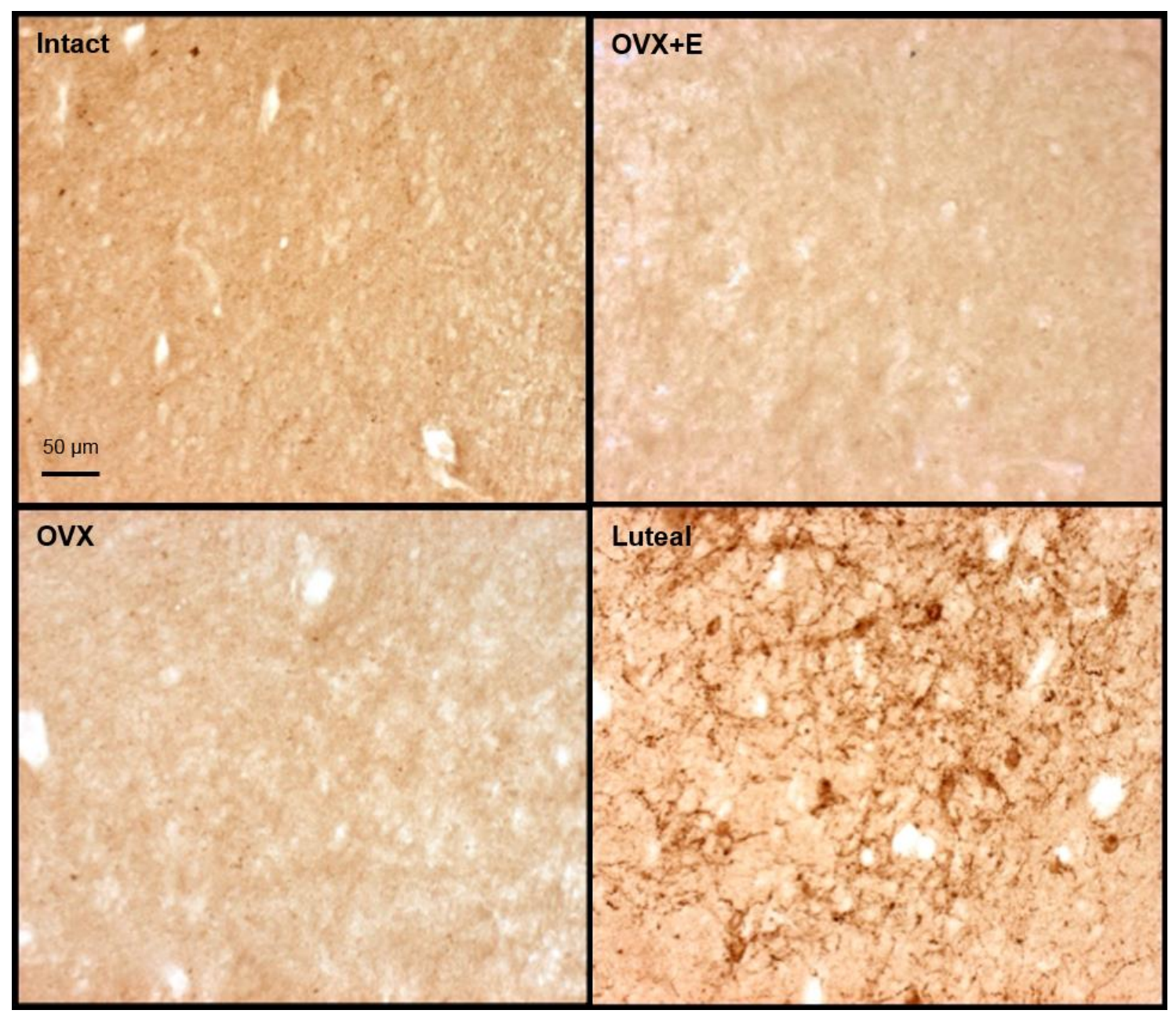

Figure 4: Representative photomicrographs of DYN within the ARC from prepubertal lambs that were ovary-intact, OVX, or OVX+E. Only sporadic DYN-labeled cells were seen in any treatment group, at any age. A section of ARC from an adult ewe taken during the luteal phase is also shown as a positive control for DYN immunostaining.

\section{Experiment 2: Will administration of a k-opioid receptor antagonist into the lateral} ventricle stimulate LH secretion?

Somewhat surprisingly, in light of the low DYN cell numbers, administration of nor-BNI increased LH pulse frequency and mean LH compared to aCSF-controls in OVX + E prepubertal animals (Fig. 5, Fig. 6A). In prepubertal OVX+E+P animals, nor-BNI significantly increased LH pulse frequency, mean LH, and LH pulse amplitude compared 
to aCSF controls $(\mathrm{p}<0.05)$ (Fig. 6B). In OVX+E postpubertal animals, there were no significant differences in LH pulse frequency, mean LH, or LH pulse amplitude between treatments (Fig. 6C). Note that in controls, both mean LH concentrations and LH pulse frequencies were higher in these older lambs than in the prepubertal group.
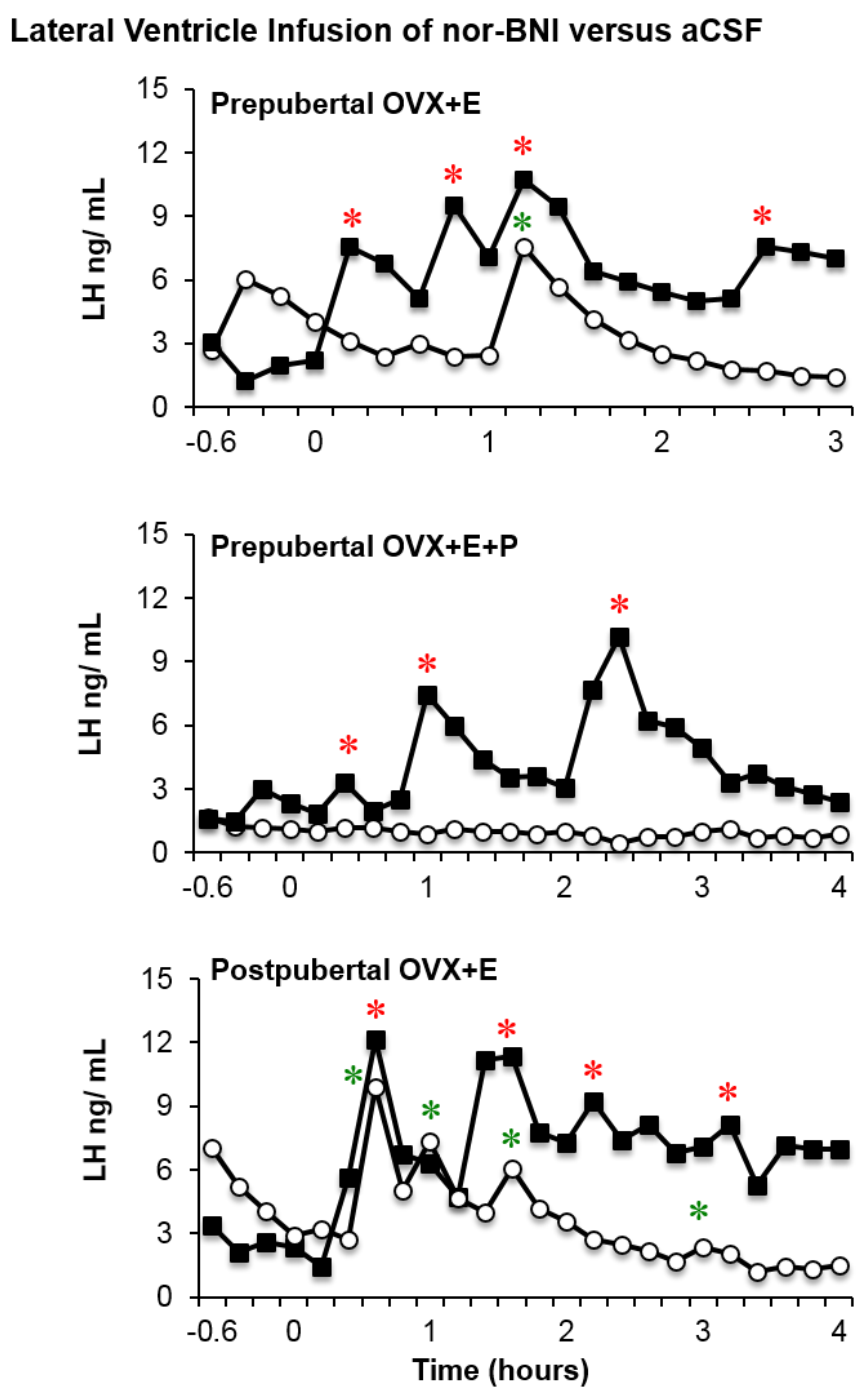

Figure 5: Representative profiles of plasma LH concentration after lateral ventricular infusion of nor-BNI (black squares) or aCSF (white open circles). Age and endocrine status are as follows: prepubertal plus estrogen implant (top), prepubertal plus estrogen implant and CIDR (progesterone) (middle), postpubertal plus estrogen implant (bottom). Time 0 equals the start of infusion. Red (nor-BNI) and green (aCSF) asterisk signify LH pulses. 


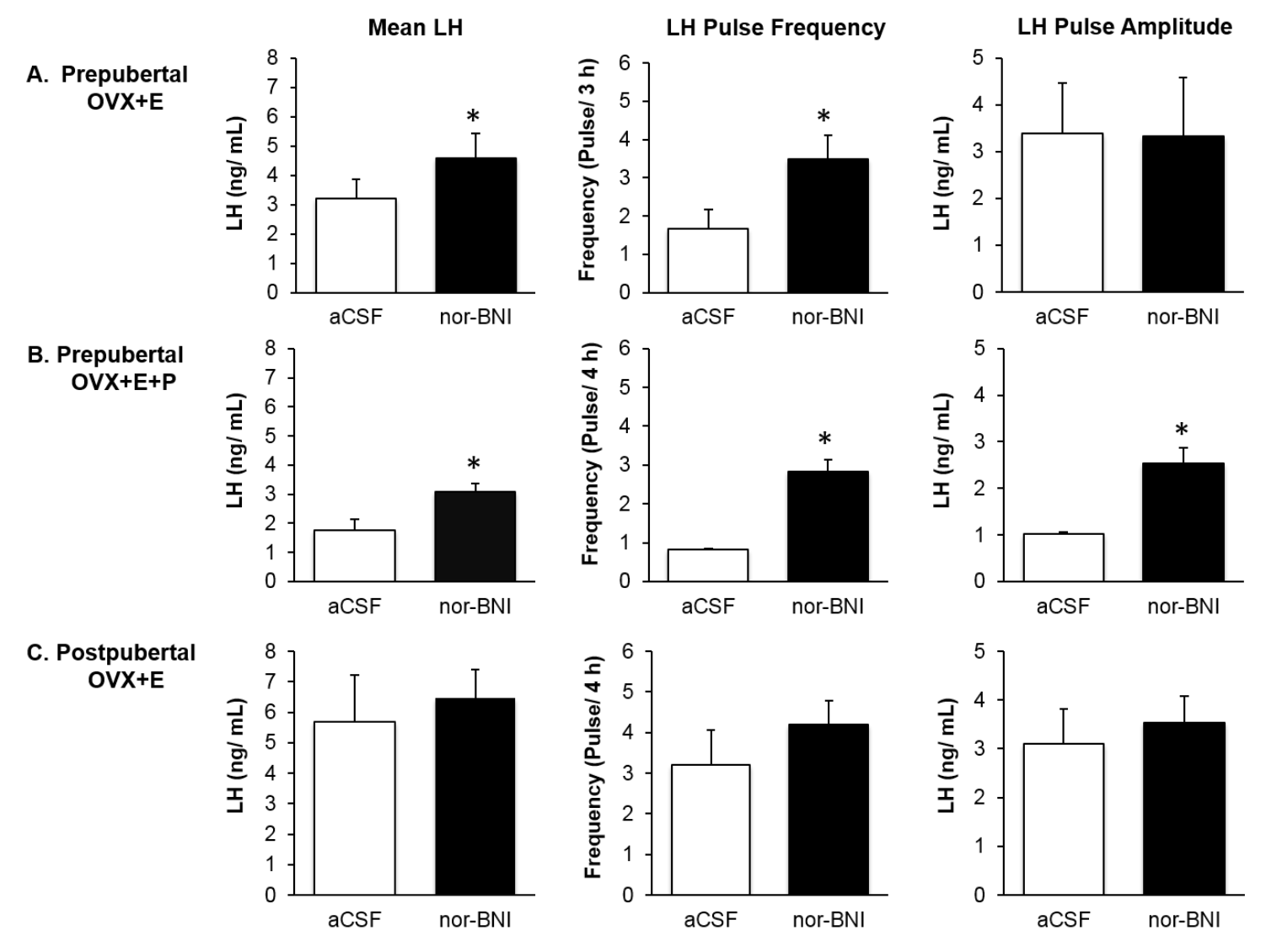

Figure 6: Mean \pm SEM for mean $\mathrm{LH}$, number of $\mathrm{LH}$ pulses, and $\mathrm{LH}$ pulse amplitude for prepubertal OVX $+\mathrm{E}(\mathrm{A})$, prepubertal $\mathrm{OVX}+\mathrm{E}+\mathrm{P}(\mathrm{B})$, and postpubertal $\mathrm{OVX}+\mathrm{E}(\mathrm{C})$ female lambs after lateral ventricle infusion of nor-BNI or aCSF. Asterisk indicates significant differences $(\mathrm{p}<0.05)$. 


\section{CHAPTER IV: DISCUSSION}

The first study examined whether changes in estrogen negative feedback in prepubertal female lambs could be mediated by inhibition of Kiss, and/or stimulation of DYN, using expression in the ARC as an index of activity. It was found that Kiss cell number in ARC decreased after administration of estrogen to ovariectomized prepubertal lambs. This outcome was in accordance with decreased mean LH and LH pulse frequency in these animals $(\mathrm{OVX}+\mathrm{E})$ and is consistent with an important role for this peptide in estrogen negative feedback in prepubertal ewes. Very few immunopositive DYN cells were observed in the ARC of any treatment or age group in experiment 1, although they were readily evident in tissue from adult luteal phase animals. In the second study, lateral ICV infusion of nor-BNI increased mean $\mathrm{LH}$ and $\mathrm{LH}$ pulse frequency in OVX+E female lambs prior to puberty, but had no effect on LH after sexual maturation. These findings support the notion that estrogen is stimulatory to, and may be acting through, DYN to inhibit LH pulse frequency prior to the onset of puberty to suppress reproduction function.

It is commonly accepted that changes in hypothalamic sensitivity to estrogen are limiting to the onset of pubertal development in females $(3,137)$. Recently, Kiss has been implicated as a potential target of estrogen negative feedback in prepubertal animals and attaining sufficient Kiss input to GnRH neurons may be the limiting factor for the initiation of sexual maturation (119). These ideas were supported by previous work in immature sheep showing that administration of Kiss stimulated GnRH and/or LH secretion prior to puberty (113). Hourly intravenous injections of Kiss initially resulted in pulse-like secretion of LH but eventually led to surge-like secretion of LH within hours after the start of treatment (113). Moreover, increases in the number of KISSI-expressing cells were 
observed in the POA of OVX+E lambs from 25 to 30 weeks of age, however, no change was seen in the same region from 30 to 35 weeks of age (117). In the ARC, no differential expression in KISS1-expressing cells in OVX+E lambs has been found, however, these cells are more plentiful in the middle ARC in animals exhibiting increased frequency of LH pulses (117). Also, increases in cell numbers of Kiss in the ARC were seen after OVX of prepubertal female lambs, but this finding was not seen in postpubertal animals (119). In the present study, cell numbers of Kiss increased in the ARC after OVX and decreased in the ARC with estrogen treatment at the time of OVX in prepubertal females, which is consistent with the hypothesis that estrogen is inhibiting Kiss secretion prior to the onset of puberty. Similar changes in cell numbers of Kiss in the ARC were observed in the older group of lambs compared to the prepubertal group, which is not consistent with a previous report (119). One likely explanation for this is that the older females were not yet postpubertal as evidenced by their lack of adult-like LH pulse frequency (Fig. 2C). Additional studies in rodents and non-human primates also imply that Kiss may initiate the emergence of reproductive function at puberty $(60,114)$. Evidence has been provided that increases in Kiss mRNA expression are found just prior to the onset of puberty in rats and monkeys and that exogenous administration of Kiss also increases LH secretion in both species prior to puberty $(107,108)$. The data reported here further support the possibility that this system (Kiss/GnRH/LH) is intact and fully functional prior to puberty; however, it is inhibited due to estrogen negative feedback.

Interestingly, very few, if any, DYN-immunoreactive cells were observed in the ARC of any treatment group, although they were readily evident in adult tissue collected during the luteal phase and concurrently assessed. These data are not consistent with the 
original hypothesis that estrogen is stimulatory to DYN prior to the onset of puberty. One interpretation of these results is that DYN may not be involved in mediating inhibitory effects of estrogen prior to the onset of puberty; but rather, DYN develops its inhibitory role via progesterone feedback post-pubertally, since it is generally accepted that DYN mediates progesterone negative feedback in adult ewes (59). Thus, the absence of DYN may be a result of reduced expression, because these animals were not in the presence of progesterone. Alternatively, there may be ongoing synthesis, balanced by high rates of transport to terminals and release of DYN during the prepubertal period. One approach to differentiating between these two explanations would be by measuring the abundance of DYN mRNA in ARC of prepubertal animals by performing in situ hybridization. Alternatively, and perhaps as a last resort, administration of colchicine (138), a microtubule-disrupting agent, could be used to block DYN protein transport out of cells within the ARC, and then measure DYN expression.

A third option to explore the role of DYN during a prepubertal state is by use of a receptor antagonist. In the current study, lateral ICV infusion of nor-BNI increased mean LH and LH pulse frequency in prepubertal, but not postpubertal, OVX+E lambs, which is consistent with the original hypothesis that endogenous DYN is playing an inhibitory role in prepubertal animals and contributing to suppression of reproductive function. In sheep, very little work has been done investigating the potential role of DYN and other endogenous opioids in prepubertal animals. Intravenous administration of naloxone, a $\mu$ receptor opioid antagonist, increased LH secretion in ovary-intact and OVX+E 12-week old prepubertal female lambs; however, this effect also was observed in postpubertal ewes (71), which is not in accordance with the present results. This can be explained by a 
difference in the receptor affinity, as naloxone is known to interact with $\mu$ - and $\kappa$-opioid receptors, while nor-BNI is highly selective for $\kappa$-receptors. In this case, DYN-א-OR signaling could be the major inhibitory pathway in prepubertal animals. Moreover, ICV infusion of nor-BNI could provide a more selective targeting of nor-BNI compared to intravenous administration of naloxone. In rodents, data have been relatively inconsistent in providing evidence for DYN in prepubertal development. Chronic intraperitoneal administration of nor-BNI tended to advance the time of vaginal opening and significantly advanced the time of first estrous (126), and increased mean LH and LH pulse frequency in immature female rats (126). Moreover, injection of anti- $\beta$-endorphin and anti-DYN antibodies into the ARC increased serum LH in prepubertal female rats (73). Alternatively, some evidence suggests that DYN may not play an inhibitory role in immature rodents. Injection of $\mu$ - or $\kappa-\mathrm{OR}$ antagonist had no effect on LH secretion in young male rats, while injection of these antagonists in older males had robust effects compared to controls (139). Moreover, injection of nor-BNI into the third ventricle of adult $\mathrm{OVX}+\mathrm{E}$ female rats decreased LH secretion, but this effect was not seen in female rats that were only ovariectomized (62), suggesting DYN may mediate negative feedback effects of estrogen in adult animals. Furthermore, DYN expression as measured by mRNA content in the ARC was significantly lower in prepubertal compared to postpubertal female rats (140); the opposite of what one would expect if loss of DYN inhibition contributed to the onset of puberty.

Aside from these possible species differences, the data reported here inidicate that DYN-k-OR signaling may contribute to the suppression of $\mathrm{GnRH} / \mathrm{LH}$ secretion in prepubertal ewes and that the tempering of DYN-k-OR activity may initiate puberty onset. 
The source(s) and sites of action of DYN, however, require further investigation. PreDYN mRNA and DYN A immunoreactive cells are widely distributed throughout the POA and hypothalamus in adult female sheep (135) and nearly $90 \%$ of DYN neurons in the POA, anterior hypothalamus, and ARC contain both estrogen (141) and progesterone receptors (58). Thus, it is conceivable that DYN neurons in regions other than the ARC may be participating in suppression of reproductive neuroendocrine function in prepubertal animals. This notion is consistent with the observation of increased LH secretion after infusion of nor-BNI in OVX+E animals, in spite of very few DYN immunopositive cells being found in the ARC of prepubertal female sheep. Moreover, DYN cells in the ARC receive projections from other DYN axons in sheep (135), suggesting some DYN-DYN interaction is possible. The most likely targets of the inhibitory effects of DYN are KNDy neurons in the ARC; however it is possible that GnRH cell bodies (59) and axon terminals are also targets of DYN inhibition, as both these populations of cells contain $\mathrm{k}-\mathrm{OR}$ in sheep (49). 


\section{CHAPTER V: SUMMARY}

In conclusion, removal of estrogen negative feedback in prepubertal ewe lambs produces increases in LH pulse frequency, mean LH, as well as number of Kiss immunoreactive cells in the ARC. These findings support the hypothesis that estrogen is inhibiting Kiss prior to the onset of puberty, specifically in this region. Contrary to the original hypothesis, very few DYN-immunopositive cells were found in any treatment group of prepubertal lambs; although, they were readily evident in tissue from an adult ewe collected during the luteal phase. However, infusion of nor-BNI significantly increased LH secretion in prepubertal animals while no effect was observed in postpubertal animals. The latter data support the original hypothesis that estrogen is stimulatory to DYN prior to the onset of puberty and that this inhibition wanes during pubertal development. Thus, it is proposed that both an increase in Kiss and a decrease in DYN contribute to the loss in responsiveness to estrogen negative feedback that occurs in during the onset of puberty in ewe lambs. 


\section{BIBLIOGRAPHY}

1. Foster DL, Ryan KD. Endocrine mechanisms governing transition into adulthood in female sheep. J. Reprod. Fertil. Suppl. 1981;30:75-90.

2. Huffman LJ, Inskeep EK, Goodman RL. Changes in episodic luteinizing hormone secretion leading to puberty in the lamb. Biol. Reprod. 1987;37(4):755761.

3. Day ML, Imakawa K, Garcia-Winder M, Zalesky DD, Schanbacher BD, Kittok RJ, Kinder JE. Endocrine mechanisms of puberty in heifers: estradiol negative feedback regulation of luteinizing hormone secretion. Biol. Reprod. 1984;31(2):332-341.

4. Schillo KK, Dierschke DJ, Hauser ER. Regulation of luteinizing hormone secretion in prepubertal heifers: increased threshold to negative feedback action of estradiol. J. Anim. Sci. 1982;54(2):325-336.

5. Kennedy GC, Mitra J. Body weight and food intake as initiating factors for puberty in the rat. J. Physiol. 1963;166(2):408-418.1.

6. Bronson FH, Manning JM. The energetic regulation of ovulation: a realistic role for body fat. Biol. Reprod. 1991;44(6):945-950.

7. Church DC. Digestive physiology and nutrition of ruminants. Volume 3. Practical nutrition. 1980:416 p.

8. Frisch RE, Hegsted DM, Yoshinaga K. Body weight and food intake at early estrus of rats on a high-fat diet. Proc. Natl. Acad. Sci. U. S. A. 1975;72(10):41724176.

9. Frisch RE, Revelle R. Height and weight at menarche and a hypothesis of menarche. Arch. Dis. Child. 1971;46(249):695-701.

10. Foster DL, Olster DH. Effect of restricted nutrition on puberty in the lamb: Patterns of tonic luteinizing hormone (LH) secretion and competency of the LH surge system. Endocrinology 1985;116(1):375-381.

11. Foster DL, Ebling FJP, Micka a. F, Vannerson L a., Bucholtz DC, Wood RI, Suttie JM, Fenner DE. Metabolic interfaces between growth and reproduction. I. Nutritional modulation of gonadotropin, prolactin, and growth hormone secretion in the growth-limited female lamb. Endocrinology 1989;125(1):342-350. 
12. Barash I a., Cheung CC, Weigle DS, Ren H, Kabigting EB, Kuijper JL, Clifton DK, Steiner $\mathbf{R}$ a. Leptin is a metabolic signal to the reproductive system. Endocrinology 1996;137(7):3144-3147.

13. Scarpace PJ, Matheny M, Pollock BH, Tümer N. Leptin increases uncoupling protein expression and energy expenditure. Am. J. Physiol. 1997;273(1 Pt 1):E226-E230.

14. Roa J, García-Galiano D, Castellano JM, Gaytan F, Pinilla L, Tena-Sempere M. Metabolic control of puberty onset: New players, new mechanisms. Mol. Cell. Endocrinol. 2010;324(1-2):87-94.

15. Nagatani S, Zeng Y, Keisler DH, Foster DL, Jaffe C a. Leptin regulates pulsatile luteinizing hormone and growth hormone secretion in the sheep. Endocrinology 2000;141(11):3965-3975.

16. Suter KJ, Pohl CR, Wilson ME. Circulating concentrations of nocturnal leptin, growth hormone, and insulin-like growth factor-I increase before the onset of puberty in agonadal male monkeys: Potential signals for the initiation of puberty. J. Clin. Endocrinol. Metab. 2000;85(2):808-814.

17. Hileman SM, Pierroz DD, Flier JS. Leptin, nutrition, and reproduction: Timing is everything. J. Clin. Endocrinol. Metab. 2000;85(2):804-807.

18. Lanes R, Gunczler P, Pasquino AM. Final adult height in short healthy children treated with growth hormone and gonadotropin-releasing hormone analogs [1] (multiple letters). J. Clin. Endocrinol. Metab. 2001;86(1):458.

19. Ahima RS, Dushay J, Flier SN, Prabakaran D, Flier JS. Leptin accelerates the onset of puberty in normal female mice. J. Clin. Invest. 1997;99(3):391-395.

20. Cheung CC, Thornton JE, Kuijper JL, Weigle DS, Clifton DK, Steiner R a. Leptin is a metabolic gate for the onset of puberty in the female rat. Endocrinology 1997;138(2):855-858.

21. Henry B a., Goding JW, Tilbrook a. J, Dunshea FR, Blache D, Clarke IJ. Leptin-mediated effects of undernutrition or fasting on luteinizing hormone and growth hormone secretion in ovariectomized ewes depend on the duration of metabolic perturbation. J. Neuroendocrinol. 2004;16(3):244-255.

22. Gruaz NM, Lalaoui M, Pierroz DD, Englaro P, Sizonenko PC, Blum WF, Aubert ML. Chronic administration of leptin into the lateral ventricle induces sexual maturation in severely food-restricted female rats. J. Neuroendocrinol. 1998;10(8):627-633. 
23. Adam CL, Findlay $\mathbf{P}$ a, Moore a $\mathbf{H}$. Effects of insulin-like growth factor-1 on luteinizing hormone secretion in sheep. Anim. Reprod. Sci. 1998;50(1-2):45-56.

24. Gabriel SM, Roncancio JR, Ruiz NS. Growth hormone pulsatility and the endocrine milieu during sexual maturation in male and female rats. Neuroendocrinology 1992;56(5):619-625.

25. Wilson ME. The impact of the GH-IGF-I axis on gonadotropin secretion: inferences from animal models. J. Pediatr. Endocrinol. Metab. 2001;14(2):115140.

26. Roberts C a, McCutcheon SN, Blair HT, Gluckman PD, Breier BH. Developmental patterns of plasma insulin-like growth factor-1 concentrations in sheep. Domest. Anim. Endocrinol. 1990;7(4):457-463.

27. Hiney JK, Srivastava V, Nyberg CL, Ojeda SR, Dees W Les. Insulin-like growth factor I of peripheral origin acts centrally to accelerate the initiation of female puberty. Endocrinology 1996;137(9):3717-3728.

28. Hiney JK, Ojeda SR, Dees WL. Insulin-like growth factor I: a possible metabolic signal involved in the regulation of female puberty. Neuroendocrinology 1991;54(4):420-423.

29. Suttie JM, Kostyo JL, Ebling FJP, Wood RI, Bucholtz DC, Skottner a., Adel TE, Towns RJ, Foster DL. Metabolic interfaces between growth and reproduction. IV. Chronic pulsatile administration of growth hormone and the timing of puberty in the female sheep. Endocrinology 1991;129(4):2024-2032.

30. Werther G, Hogg a, Oldfield B, McKinley M, Figdor R, Allen A, Mendelsohn F. Localization and characterization of insulin receptors in rat brain and pituitary gland using in vitro autoradiography and computerized densitometry. Endocrinology 1987;121(4):1562-70.

31. Williams NI, Lancas MJ, Cameron JL. Stimulation of luteinizing hormone secretion by food intake: evidence against a role for insulin. Endocrinology 1996;137(6):2565-2571.

32. Hileman SM, Schillo KK, Hall JB. Effects of acute, intracerebroventricular administration of insulin on serum concentrations of luteinizing hormone, insulin, and glucose in ovariectomized lambs during restricted and ad libitum feed intake. Biol. Reprod. 1993;48(1):117-124.

33. Ritter S, Dinh TT, Zhang Y. Localization of hindbrain glucoreceptive sites controlling food intake and blood glucose. Brain Res. 2000;856(1-2):37-47. 
34. Schneider JE, Goldman MD, Leo $\mathbf{N}$ a, Rosen ME. Central vs. peripheral metabolic control of estrous cycles in Syrian hamsters. II. Glucoprivation. Am. J. Physiol. 1997;272(1 Pt 2):R406-R412.

35. Ohkura S, Tanaka T, Nagatani S, Bucholtz DC, Tsukamura H, Maeda KI, Foster DL. Central, but not peripheral, glucose-sensing mechanisms mediate glucoprivic suppression of pulsatile luteinizing hormone secretion in the sheep. Endocrinology 2000;141(12):4472-4480.

36. I'Anson H, Sundling L a., Roland SM, Ritter S. Immunotoxic destruction of distinct catecholaminergic neuron populations disrupts the reproductive response to glucoprivation in female rats. Endocrinology 2003;144(10):4325-4331.

37. Yeates NTM. The breeding season of the sheep with particular reference to its modification by artificial means using light. J. Agric. Sci. 1949;39(01):1.

38. Yellon SM, Foster DL. Melatonin rhythms time photoperiod-induced puberty in the female lamb. Endocrinology 1986;119(1):44-49.

39. Karsch FJ, Bittman EL, Foster DL, Goodman RL, Legan SJ, Robinson JE. Neuroendocrine basis of seasonal reproduction. Recent Prog. Horm. Res. 1984;40:185-232.

40. Fletcher I, Geytenbeek P. Seasonal variation in the ovarian activity of Merino ewes. Aust. J. Exp. Agric. 1970;10(44):267.

41. Goodman RL, Hileman SM, Nestor CC, Porter KL, Connors JM, Hardy SL, Millar RP, Cernea M, Coolen LM, Lehman MN. Kisspeptin, neurokinin B, and dynorphin act in the arcuate nucleus to control activity of the GnRH pulse generator in ewes. Endocrinology 2013;154(11):4259-4269.

42. Senger PL. Pathways to Pregnancy and Parturition (sec Ed).pdf. 2003:373.

43. Maeda KI, Adachi S, Inoue K, Ohkura S, Tsukamura H. Metastin/Kisspeptin and control of estrous cycle in rats. Rev. Endocr. Metab. Disord. 2007;8(1):21-29.

44. Plant TM, Krey LC, Moossy J, McCormack JT, Hess DL, Knobil E. The arcuate nucleus and the control of gonadotropin and prolactin secretion in the female rhesus monkey (Macaca mulatta). Endocrinology 1978;102(1):52-62.

45. Smith JT, Cunningham MJ, Rissman EF, Clifton DK, Steiner R a. Regulation of Kiss 1 gene expression in the brain of the female mouse. Endocrinology 2005;146(9):3686-3692.

46. Goodman RL, Lehman MN, Smith JT, Coolen LM, De Oliveira CVR, Jafarzadehshirazi MR, Pereira A, Iqbal J, Caraty A, Ciofi P, Clarke IJ. 
Kisspeptin neurons in the arcuate nucleus of the ewe express both dynorphin A and neurokinin B. Endocrinology 2007;148(12):5752-5760.

47. Lehman MN, Ebling FJP, Moenter SM, Karsch FJ. Distribution of estrogen receptor-immunoreactive cells in the sheep brain. Endocrinology 1993;133(2):876-886.

48. Petersen SL, Ottem EN, Carpenter CD. Direct and indirect regulation of gonadotropin-releasing hormone neurons by estradiol. Biol. Reprod. 2003;69(6):1771-1778.

49. Lehman MN, Coolen LM, Goodman RL. Minireview: Kisspeptin/neurokinin B/dynorphin (KNDy) cells of the arcuate nucleus: A central node in the control of gonadotropin-releasing hormone secretion. Endocrinology 2010;151(8):34793489.

50. Lehman MN, Hileman SM, Goodman RL. Neuroanatomy of the kisspeptin signaling system in mammals: Comparative and developmental aspects. Adv. Exp. Med. Biol. 2013;784:27-62.

51. Smith JT, Coolen LM, Kriegsfeld LJ, Sari IP, Jaafarzadehshirazi MR, Maltby M, Bateman K, Goodman RL, Tilbrook AJ, Ubuka T, Bentley GE, Clarke IJ, Lehman MN. Variation in kisspeptin and RFamide-related peptide (RFRP) expression and terminal connections to gonadotropin-releasing hormone neurons in the brain: A novel medium for seasonal breeding in the sheep. Endocrinology 2008;149(11):5770-5782.

52. Wiegand SJ, Terasawa E, Bridson WE, Goy RW. Effects of discrete lesions of preoptic and suprachiasmatic structures in the female rat. Alterations in the feedback regulation of gonadotropin secretion. Neuroendocrinology 1980;31(2):147-157.

53. Wiegand SJ, Terasawa E. Discrete lesions reveal functional heterogeneity of suprachiasmatic structures in regulation of gonadotropin secretion in the female rat. Neuroendocrinology 1982;34(6):395-404.

54. Herbison AE. Estrogen positive feedback to gonadotropin-releasing hormone $(\mathrm{GnRH})$ neurons in the rodent: The case for the rostral periventricular area of the third ventricle (RP3V). Brain Res. Rev. 2008;57(2):277-287.

55. Smith JT, Li Q, Pereira a., Clarke IJ. Kisspeptin neurons in the ovine arcuate nucleus and preoptic area are involved in the preovulatory luteinizing hormone surge. Endocrinology 2009;150(12):5530-5538.

56. Caraty a., Fabre-Nys C, Delaleu B, Locatelli a., Bruneau G, Karsch FJ, Herbison a. Evidence that the mediobasal hypothalamus is the primary site of 
action of estradiol in inducing the preovulatory gonadotropin releasing hormone surge in the ewe. Endocrinology 1998;139(4):1752-1760.

57. Smith JT, Li Q, Yap KS, Shahab M, Roseweir AK, Millar RP, Clarke IJ. Kisspeptin is essential for the full preovulatory LH surge and stimulates GnRH release from the isolated ovine median eminence. Endocrinology 2011;152(3):1001-1012.

58. Foradori CD, Coolen LM, Fitzgerald ME, Skinner DC, Goodman RL, Lehman MN. Colocalization of progesterone receptors in parvicellular dynorphin neurons of the ovine preoptic area and hypothalamus. Endocrinology 2002;143(11):4366-4374.

59. Goodman RL, Coolen LM, Anderson GM, Hardy SL, Valent M, Connors JM, Fitzgerald ME, Lehman MN. Evidence that dynorphin plays a major role in mediating progesterone negative feedback on gonadotropin-releasing hormone neurons in sheep. Endocrinology 2004;145(6):2959-2967.

60. Shahab M, Mastronardi C, Seminara SB, Crowley WF, Ojeda SR, Plant TM. Increased hypothalamic GPR54 signaling: a potential mechanism for initiation of puberty in primates. Proc. Natl. Acad. Sci. U. S. A. 2005;102(6):2129-2134.

61. Li XF, Kinsey-Jones JS, Cheng Y, Knox AMI, Lin Y, Petrou N a., Roseweir A, Lightman SL, Milligan SR, Millar RP, O'Byrne KT. Kisspeptin signalling in the hypothalamic arcuate nucleus regulates $\mathrm{GnRH}$ pulse generator frequency in the rat. PLoS One 2009;4(12). doi:10.1371/journal.pone.0008334.

62. Mostari P, Ieda N, Deura C, Minabe S, Yamada S, Uenoyama Y, Maeda K, Tsukamura H. dynorphin-kappa opioid receptor signaling partly mediates estrogen negative feedback effect on LH pulses in female rats. J. Reprod. Dev. 2013;59(3):266-72.

63. Gallo R V. Kappa-opioid receptor involvement in the regulation of pulsatile luteinizing hormone release during early pregnancy in the rat. J. Neuroendocrinol. 1990;2(5):685-691.

64. Foster DL, Ryan KD, Papkoff H. Hourly administration of luteinizing hormone induces ovulation in prepubertal female sheep. Endocrinology 1984;115(3):11791185.

65. Keisler DH, Inskeep EK, Dailey $\mathbf{R}$ a. Roles of pattern of secretion of luteinizing hormone and the ovary in attainment of puberty in ewes lambs. Domest. Anim. Endocrinol. 1985;2(3):123-132. 
66. Foster DL, Karsch FJ. Development of the mechanism regulating the preovulatory surge of luteinizing hormone in sheep. Endocrinology 1975;97(5):1205-1209.

67. Sullivan K a, Witkin JW, Ferin M, Silverman a J. Gonadotropin-releasing hormone neurons in the rhesus macaque are not immunoreactive for the estrogen receptor. Brain Res. 1995;685(1-2):198-200.

68. Urbanski HF, Ojeda SR. Activation of luteinizing hormone-releasing hormone release advances the onset of female puberty. Neuroendocrinology 1987;46(3):273-276.

69. Gay VL, Plant TM. N-methyl-D,L-aspartate elicits hypothalamic gonadotropinreleasing hormone release in prepubertal male rhesus monkeys (Macaca mulatta). Endocrinology 1987;120(6):2289-2296.

70. Ebling FJP, Wood RI, Karsch FJ, Vannerson L a., Suttie JM, Bucholtz DC, Schall RE, Foster DL. Metabolic interfaces between growth and reproduction. III. Central mechanisms controlling pulsatile luteinizing hormone secretion in the nutritionally growth-limited female lamb. Endocrinology 1990;126(5):2719-2727.

71. Schall RE, Ebling FJ, Karsch FJ, Foster DL. Postpubertal maturation of endogenous opioid regulation of luteinizing hormone secretion in the female sheep. Biol. Reprod. 1991;44(5):760-768.

72. I'Anson H, Manning JM, Herbosa CG, Pelt J, Friedman CR, Wood RI, Bucholtz DC, Foster DL. Central inhibition of gonadotropin-releasing hormone secretion in the growth-restricted hypogonadotropic female sheep. Endocrinology 2000;141(2):520-527.

73. Schulz R, Wilhelm a, Pirke KM, Gramsch C, Herz a. Beta-endorphin and dynorphin control serum luteinizing hormone level in immature female rats. Nature 1981;294(5843):757-759.

74. Cagampang FR a, Maeda KI, Tsukamura H, Phkura S, Ota K. Involvement of ovarian steroids and endogenous opioids in the fasting-induced suppression of pulsatile LH release in ovariectomized rats. J. Endocrinol. 1991;129(3):321-328.

75. Briski KP, Quigley K, Meites J. Endogenous opiate involvement in acute and chronic stress-induced changes in plasma LH concentrations in the male rat. Life Sci. 1984;34(25):2485-2493.

76. Cunningham MJ, Clifton DK, Steiner R a. Leptin's actions on the reproductive axis: perspectives and mechanisms. Biol. Reprod. 1999;60(2):216-222. 
77. Morris BJ. Neuronal localisation of neuropeptide $\mathrm{Y}$ gene expression in rat brain. J. Comp. Neurol. 1989;290(3):358-368.

78. Tang-Christensen M, Havel PJ, Jacobs RR, Larsen PJ, Cameron JL. Central administration of leptin inhibits food intake and activates the sympathetic nervous system in rhesus macaques. J. Clin. Endocrinol. Metab. 1999;84(2):711-717.

79. Williams LM, Adam CL, Mercer JG, Moar KM, Slater D, Hunter L, Findlay $P$ a., Hoggard N. Leptin receptor and neuropeptide Y gene expression in the sheep brain. J. Neuroendocrinol. 1999;11(3):165-169.

80. Williams G, Cai XJ, Elliott JC, Harrold JA. Anabolic neuropeptides. Physiol. Behav. 2004;81(2):211-222.

81. Kalra SP, Kalra PS. Nutritional infertility: the role of the interconnected hypothalamic neuropeptide Y-galanin-opioid network. Front. Neuroendocrinol. 1996;17(4):371-401.

82. Hâkansson ML, Brown H, Ghilardi N, Skoda RC, Meister B. Leptin receptor immunoreactivity in chemically defined target neurons of the hypothalamus. $J$. Neurosci. 1998;18(1):559-572.

83. Mercer JG, Hoggard N, Williams LM, Lawrence CB, Hannah LT, Morgan PJ, Trayhurn P. Coexpression of leptin receptor and preproneuropeptide $\mathrm{Y}$ mRNA in arcuate nucleus of mouse hypothalamus. J. Neuroendocrinol. 1996;8(10):733-735.

84. Finn PD, Cunningham MJ, Pau KYF, Spies HG, Clifton DK, Steiner R a. The stimulatory effect of leptin on the neuroendocrine reproductive axis of the monkey. Endocrinology 1998;139(11):4652-4662.

85. Dyer CJ, Simmons JM, Matteri RL, Keisler DH. Leptin receptor mRNA is expressed in ewe anterior pituitary and adipose tissues and is differentially expressed in hypothalamic regions of well-fed and feed-restricted ewes. Domest. Anim. Endocrinol. 1997;14(2):119-128.

86. Tatemoto K. Neuropeptide Y: history and overview. Neuropept. Y Relat. Pept. 2004.

87. Stephens TW, Basinski M, Bristow PK, Bue-Valleskey JM, Burgett SG, Craft L, Hale J, Hoffmann J, Hsiung HM, Kriauciunas a. The role of neuropeptide Y in the antiobesity action of the obese gene product. Nature 1995;377(6549):530532. 
88. Jackson PJ, Douglas NR, Chai B, Binkley J, Sidow A, Barsh GS, Millhauser GL. Structural and Molecular Evolutionary Analysis of Agouti and AgoutiRelated Proteins. Chem. Biol. 2006;13(12):1297-1305.

89. Sheffer-Babila S, Sun Y, Israel DD, Liu S-M, Neal-Perry G, Chua SC. Agoutirelated peptide plays a critical role in leptin's effects on female puberty and reproduction. Am. J. Physiol. Endocrinol. Metab. 2013;305(12):E1512-20.

90. Henry B a., Rao A, Ikenasio B a., Mountjoy KG, Tilbrook AJ, Clarke IJ. Differential expression of cocaine- and amphetamine-regulated transcript and agouti related-protein in chronically food-restricted sheep. Brain Res. 2001;918(12):40-50.

91. Mizuno TM, Kleopoulos SP, Bergen HT, Roberts JL, Priest C a., Mobbs C V. Hypothalamic pro-opiomelanocortin mRNA is reduced by fasting in ob/ob and $\mathrm{db} / \mathrm{db}$ mice, but is stimulated by leptin. Diabetes 1998;47(2):294-297.

92. Cravo RM, Margatho LO, Osborne-Lawrence S, Donato J, Atkin S, Bookout a. L, Rovinsky S, Frazão R, Lee CE, Gautron L, Zigman JM, Elias CF. Characterization of Kiss1 neurons using transgenic mouse models. Neuroscience 2011;173:37-56.

93. Leranth C, MacLusky NJ, Shanabrough M, Naftolin F. Immunohistochemical evidence for synaptic connections between pro-opiomelanocortin-immunoreactive axons and LH-RH neurons in the preoptic area of the rat. Brain Res. 1988;449(12):167-176.

94. Schiöth HB, Watanobe H. Melanocortins and reproduction. Brain Res. Rev. 2002;38(3):340-350.

95. Backholer K, Bowden M, Gamber K, Bjørbak C, Iqbal J, Clarke IJ. Melanocortins mimic the effects of leptin to restore reproductive function in lean hypogonadotropic ewes. Neuroendocrinology 2010;91(1):27-40.

96. Cheng G. Coolen LM. Padmanabhan V. Goodman RL. Lehman M. The kisspeptin/neurokinin B/dynorphin (KNDy) cell population of the arcuate nucleus: sex differences and effects of prenatal. Endocrinology 2010;151(1):301-311.

97. Backholer K, Smith JT, Rao A, Pereira A, Iqbal J, Ogawa S, Li Q, Clarke IJ. Kisspeptin cells in the ewe brain respond to leptin and communicate with neuropeptide Y and proopiomelanocortin cells. Endocrinology 2010;151(5):22332243.

98. Louis GW, Greenwald-Yarnell M, Phillips R, Coolen LM, Lehman MN, Myers MG. Molecular mapping of the neural pathways linking leptin to the neuroendocrine reproductive axis. Endocrinology 2011;152(6):2302-2310. 
99. Qiu X, Dowling AR, Marino JS, Faulkner LD, Bryant B, Brüning JC, Elias CF, Hill JW. Delayed puberty but normal fertility in mice with selective deletion of insulin receptors from kiss1 cells. Endocrinology 2013;154(3):1337-1348.

100. Smith JT, Acohido B V., Clifton DK, Steiner R a. KiSS-1 neurones are direct targets for leptin in the ob/ob mouse. J. Neuroendocrinol. 2006;18(4):298-303.

101. Cravo RM, Frazao R, Perello M, Osborne-Lawrence S, Williams KW, Zigman JM, Vianna C, Elias CF. Leptin Signaling in Kiss1 Neurons Arises after Pubertal Development. PLoS One 2013;8(3). doi:10.1371/journal.pone.0058698.

102. Castellano JM, Navarro VM, Fernández-Fernández R, Nogueiras R, Tovar S, Roa J, Vazquez MJ, Vigo E, Casanueva FF, Aguilar E, Pinilla L, Dieguez C, Tena-Sempere M. Changes in hypothalamic KiSS-1 system and restoration of pubertal activation of the reproductive axis by kisspeptin in undernutrition. Endocrinology 2005;146(9):3917-3925.

103. Kotani M, Detheux M, Vandenbogaerde A, Communi D, Vanderwinden JM, Le Poul E, Brézillon S, Tyldesley R, Suarez-Huerta N, Vandeput F, Blanpain C, Schiffmann SN, Vassart G, Parmentier M. The Metastasis Suppressor Gene KiSS-1 Encodes Kisspeptins, the Natural Ligands of the Orphan G Proteincoupled Receptor GPR54. J. Biol. Chem. 2001;276(37):34631-34636.

104. Muir a I, Chamberlain L, Elshourbagy N a, Michalovich D, Moore DJ, Calamari a, Szekeres PG, Sarau HM, Chambers JK, Murdock P, Steplewski K, Shabon U, Miller JE, Middleton SE, Darker JG, Larminie CG, Wilson S, Bergsma DJ, Emson P, Faull R, Philpott KL, Harrison DC, Axor12. a novel human G protein-coupled receptor, activated by the peptide. KiSS-1, J. Biol. Chem. 2001;276:28969-28975.

105. Ohtaki T, Shintani Y, Honda S, Matsumoto H, Hori a, Kanehashi K, Terao Y, Kumano S, Takatsu Y, Masuda Y, Ishibashi Y, Watanabe T, Asada M, Yamada T, Suenaga M, Kitada C, Usuki S, Kurokawa T, Onda H, Nishimura O, Fujino M. Metastasis suppressor gene KiSS-1 encodes peptide ligand of a Gprotein-coupled receptor. Nature 2001;411(6837):613-617.

106. Seminara SB, Messager S, Chatzidaki EE, Thresher RR, Acierno JS, Shagoury JK, Bo-Abbas Y, Kuohung W, Schwinof KM, Hendrick AG, Zahn D, Dixon J, Kaiser UB, Slaugenhaupt S a, Gusella JF, O'Rahilly S, Carlton MBL, Crowley WF, Aparicio S a JR, Colledge WH. The GPR54 gene as a regulator of puberty. N. Engl. J. Med. 2003;349(17):1614-1627.

107. Navarro VM, Gottsch ML, Chavkin C, Okamura H, Clifton DK, Steiner R a. Regulation of gonadotropin-releasing hormone secretion by kisspeptin/dynorphin/neurokinin B neurons in the arcuate nucleus of the mouse. $J$. Neurosci. 2009;29(38):11859-11866. 
108. Plant TM, Ramaswamy S, DiPietro MJ. Repetitive activation of hypothalamic G protein-coupled receptor 54 with intravenous pulses of kisspeptin in the juvenile monkey (Macaca mulatta) elicits a sustained train of gonadotropin-releasing hormone discharges. Endocrinology 2006;147(2):1007-1013.

109. Messager S, Chatzidaki EE, Ma D, Hendrick AG, Zahn D, Dixon J, Thresher RR, Malinge I, Lomet D, Carlton MBL, Colledge WH, Caraty A, Aparicio S a JR. Kisspeptin directly stimulates gonadotropin-releasing hormone release via $\mathrm{G}$ protein-coupled receptor 54. Proc. Natl. Acad. Sci. U. S. A. 2005;102(5):17611766.

110. Kadokawa H, Matsui M, Hayashi K, Matsunaga N, Kawashima C, Shimizu T, Kida K, Miyamoto a. Peripheral administration of kisspeptin-10 increases plasma concentrations of GH as well as LH in prepubertal Holstein heifers. J. Endocrinol. 2008;196(2):331-334.

111. Navarro VM, Fernández-Fernández R, Castellano JM, Roa J, Mayen a, Barreiro ML, Gaytan F, Aguilar E, Pinilla L, Dieguez C, Tena-Sempere M. Advanced vaginal opening and precocious activation of the reproductive axis by KiSS-1 peptide, the endogenous ligand of GPR54. J. Physiol. 2004;561(Pt 2):379386.

112. Plant TM, Ramaswamy S, DiPietro MJ. Repetitive activation of hypothalamic G protein-coupled receptor 54 with intravenous pulses of kisspeptin in the juvenile monkey (Macaca mulatta) elicits a sustained train of gonadotropin-releasing hormone discharges. Endocrinology 2006;147(2):1007-1013.

113. Redmond JS, Macedo GG, Velez IC, Caraty a., LWilliams G, Amstalden M. Kisspeptin activates the hypothalamic-adenohypophyseal-gonadal axis in prepubertal ewe lambs. Reproduction 2011;141(4):541-548.

114. Navarro VM, Castellano JM, Fernández-Fernández R, Barreiro ML, Roa J, Sanchez-Criado JE, Aguilar E, Dieguez C, Pinilla L, Tena-Sempere M. Developmental and hormonally regulated messenger ribonucleic acid expression of KiSS-1 and its putative receptor, GPR54, in rat hypothalamus and potent luteinizing hormone-releasing activity of KiSS-1 peptide. Endocrinology 2004;145(10):4565-4574.

115. Han S-K, Gottsch ML, Lee KJ, Popa SM, Smith JT, Jakawich SK, Clifton DK, Steiner R a, Herbison AE. Activation of gonadotropin-releasing hormone neurons by kisspeptin as a neuroendocrine switch for the onset of puberty. $J$. Neurosci. 2005;25(49):11349-11356.

116. Clarkson J, Herbison AE. Postnatal development of kisspeptin neurons in mouse hypothalamus; sexual dimorphism and projections to gonadotropin-releasing hormone neurons. Endocrinology 2006;147(12):5817-5825. 
117. Redmond JS, Baez-Sandoval GM, Spell KM, Spencer TE, Lents C a., Williams GL, Amstalden M. Developmental Changes in Hypothalamic Kiss 1 Expression during Activation of the Pulsatile Release of Luteinising Hormone in Maturing Ewe Lambs. J. Neuroendocrinol. 2011;23(9):815-822.

118. Tena-Sempere M, Kauffman a. S, Roa J, Navarro VM, Gottsch ML, Clifton DK, Steiner R a. Sexual differentiation of Kiss1 expression in the brain of the rat. Front. Neuroendocrinol. 2006;27(1):97.

119. Nestor CC, Briscoe AMS, Davis SM, Valent M, Goodman RL, Hileman SM. Evidence of a role for kisspeptin and neurokinin B in puberty of female sheep. Endocrinology 2012;153(6):2756-2765.

120. Sheehan HL, Kovács K. The subventricular nucleus of the human hypothalamus. Brain 1966;89(3):589-614.

121. Topaloglu a K, Reimann F, Guclu M, Yalin AS, Kotan LD, Porter KM, Serin A, Mungan NO, Cook JR, Ozbek MN, Imamoglu S, Akalin NS, Yuksel B, O'Rahilly S, Semple RK. TAC3 and TACR3 mutations in familial hypogonadotropic hypogonadism reveal a key role for Neurokinin B in the central control of reproduction. Nat. Genet. 2009;41(3):354-358.

122. Rance NE, Bruce TR. Neurokinin B gene expression is increased in the arcuate nucleus of ovariectomized rats. Neuroendocrinology 1994;60(4):337-345.

123. Porter KL, Hileman SM, Hardy SL, Nestor CC, Lehman MN, Goodman RL. Neurokinin-3 Receptor Activation in the Retrochiasmatic Area is Essential for the Full Preovulatory LH Surge in Ewes. J. Neuroendocrinol. 2014. doi:10.1111/jne.12180.

124. Billings HJ, Connors JM, Altman SN, Hileman SM, Holaskova I, Lehman MN, McManus CJ, Nestor CC, Jacobs BH, Goodman RL. Neurokinin B acts via the neurokinin-3 receptor in the retrochiasmatic area to stimulate luteinizing hormone secretion in sheep. Endocrinology 2010;151(8):3836-3846.

125. Sandoval-Guzmán T, Rance NE. Central injection of senktide, an NK3 receptor agonist, or neuropeptide $\mathrm{Y}$ inhibits LH secretion and induces different patterns of Fos expression in the rat hypothalamus. Brain Res. 2004;1026(2):307-312.

126. Nakahara T, Uenoyama Y, Iwase A, Oishi S, Nakamura S, Minabe S, Watanabe Y, Deura C, Noguchi T, Fujii N, Kikkawa F, Maeda KI, Tsukamura H. Chronic Peripheral Administration of Kappa-Opioid Receptor Antagonist Advances Puberty Onset Associated with Acceleration of Pulsatile Luteinizing Hormone Secretion in Female Rats. J Reprod Dev 2013. 
127. Li SY, Li XF, Hu MH, Shao B, Poston L, Lightman SL, O'Byrne KT. Neurokinin B Receptor Antagonism Decreases Luteinising Hormone Pulse Frequency and Amplitude and Delays Puberty Onset in the Female Rat. $J$. Neuroendocrinol. 2014;26(8):521-527.

128. Ramaswamy S, Seminara SB, Ali B, Ciofi P, Amin N a., Plant TM. Neurokinin B stimulates GnRH release in the male monkey (Macaca mulatta) and is colocalized with kisspeptin in the arcuate nucleus. Endocrinology 2010;151(9):4494-4503.

129. Nestor CC, Briscoe AMS, Davis SM, Valent M, Goodman RL, Hileman SM. Evidence of a role for kisspeptin and neurokinin B in puberty of female sheep. Endocrinology 2012;153(6):2756-2765.

130. Schall RE, Ebling FJ, Karsch FJ, Foster DL. Postpubertal maturation of endogenous opioid regulation of luteinizing hormone secretion in the female sheep. Biol. Reprod. 1991;44(5):760-768.

131. Foster DL, Jackson LM, Padmanabhan V. Programming of GnRH feedback controls timing puberty and adult reproductive activity. Mol. Cell. Endocrinol. 2006;254-255:109-119.

132. Cesario SK, Hughes L a. Precocious puberty: a comprehensive review of literature. J Obs. Gynecol Neonatal Nurs 2007;36(3):263-274.

133. Kaplowitz PB, Slora EJ, Wasserman RC, Pedlow SE, Herman-Giddens ME. Earlier onset of puberty in girls: relation to increased body mass index and race. Pediatrics 2001;108(2):347-353.

134. Wakabayashi Y, Nakada T, Murata K, Ohkura S, Mogi K, Navarro VM, Clifton DK, Mori Y, Tsukamura H, Maeda K-I, Steiner R a, Okamura H. Neurokinin B and dynorphin A in kisspeptin neurons of the arcuate nucleus participate in generation of periodic oscillation of neural activity driving pulsatile gonadotropin-releasing hormone secretion in the goat. J. Neurosci. 2010;30(8):3124-3132.

135. Foradori CD, Goodman RL, Lehman MN. Distribution of preprodynorphin mRNA and dynorphin-A immunoreactivity in the sheep preoptic area and hypothalamus. Neuroscience 2005;130(2):409-418.

136. Whisnant CS, Goodman RL. Effects of an opioid antagonist on pulsatile luteinizing hormone secretion in the ewe vary with changes in steroid negative feedback. Biol. Reprod. 1988;39(5):1032-1038.

137. Ebling FJ, Kushler RH, Foster DL. Pulsatile LH secretion during sexual maturation in the female sheep: photoperiodic regulation in the presence and 
absence of ovarian steroid feedback as determined in the same individual.

Neuroendocrinology 1990;52(3):229-237.

138. Chalivoix S, Bagnolini a., Caraty a., Cognié J, Malpaux B, Dufourny L.

Effects of photoperiod on kisspeptin neuronal populations of the ewe diencephalon in connection with reproductive function. J. Neuroendocrinol. 2010;22(2):110118.

139. Cicero TJ, Meyer ER, Miller BT, Bell RD. Age-related differences in the sensitivity of serum luteinizing hormone to prototypic mu, kappa and delta opiate agonists and antagonists. J. Pharmacol. Exp. Ther. 1988;246(1):14-20.

140. Ciofi P, Lapirot OC, Tramu G. An androgen-dependent sexual dimorphism visible at puberty in the rat hypothalamus. Neuroscience 2007;146(2):630-642.

141. Gintzler AR, Schnell S a, Gupta DS, Liu N-J, Wessendorf MW. Relationship of spinal dynorphin neurons to delta-opioid receptors and estrogen receptor alpha: anatomical basis for ovarian sex steroid opioid antinociception. J. Pharmacol. Exp. Ther. 2008;326(3):725-731. 
West Virginia University

Department of Physiology and Pharmacology

P.O. Box 9229

Morgantown WV 26505

Phone: (704) 989-6845

Email: jnlopez@mix.wvu.edu

\section{Education:}

2012 Bachelor of Arts, Biology

2015 Master of Science, Reproductive Physiology
Wingate University

West Virginia University

\section{Research Experience:}

June 2012 - December 2012

Research Assistant: Laboratory of Dr. Sandra Petersen, Ph.D.

University of Massachusetts, Amherst, Department of Veterinary and Animal

Sciences, Amherst, MA

Project: Neudesin Expression in the Developing and Adult Rat Preoptic Area and Hypothalamus

- Performed immunocytochemistry and in situ hybridization on whole brain tissue sections to assess hypothalamic protein expression and mRNA content, respectively

- Performed quantitative-real-time polymerase chain reaction to quantify targeted DNA

- Tissue sectioning - whole brain tissue sectioning using a cryostat

January 2013 - Present

Graduate Research Assistant: Laboratories of Dr. Robert Goodman, Ph.D. and Dr. Stanley Hileman, West Virginia University, Department of Physiology and Pharmacology, Morgantown, WV

Project: Evidence that Alterations in DYN Secretion Play an Important Role in Ovine Sexual Maturation 
- Performed immunohistochemistry on hypothalamic tissue to assess protein expression (including but not limited to Kiss and DYN)

- Venipuncture for blood collection (ovine)

- Insertion of jugular catheters

- Neurosurgery: stereotaxic insertion of chronic guide tubes in specific brain areas (ARC, POA)

- General surgery: bilateral ovariectomy

- Tissue sectioning: hypothalamic tissue blocks using a freezing microtome

- Microinjection or microinfusion of neuropeptides or receptor agonists or antagonists into the third or lateral cerebroventricle (ovine)

\section{Publications:}

Petersen SL, Krishnan S, Aggison LK, Intlekofer K, Moura-Conlon PJ, Brewer DN, del Pino Sans J, Lopez JA. Sexual differentiation of the gonadotropin surge release mechanism: a new role for the canonical $\mathrm{Nf \kappa B}$ signaling pathway. Front Neuroendocrinol 2012; 33:36-44.

Petersen SL, Intlekofer KA, Moura-Conlon PJ, Brewer DN, del Pino Sans J, Lopez JA. Nonclassical progesterone signaling molecules in the nervous system. J Neuroendocrinol 2013; 25:991-1001.

\section{Abstracts:}

Lopez JA, del Pino Sans J, Petersen SL. 2012 Neudesin expression in the developing and adult rats preoptic area and hypothalamus. Annual Biomedical Research Conference for Minority Students (San Francisco, CA)

Grachev P, McCosh RB, Lopez JA, Meadows LJ, Nesselrod GL, Valent M, Hardy SL, Connors JM, Hileman SM, and Goodman RL. 2014 Surge-like LH secretion induced by retrochiasmatic area NK3R activation is mediated by Kiss/GPR54 signaling in ovary-intact ewes. International Congress of Neuroendocrinology (Hilton Sydney, Australia)

Lopez JA, Wisman BR, Meadows LJ, McCosh RB, Goodman RL, and Hileman SM. 2014 Is DYN involved in the prepubertal suppression of LH secretion by estradiol in female sheep? Annual meeting of the Society for Neuroscience (Washington D.C.)

Lopez JA, McCosh RB, Nesselrod GL, Bedenbaugh MN, Hardy SL, Goodman RL, and Hileman SM. 2014 Evidence that alterations in DYN secretion play an important role in ovine sexual maturation. Annual meeting of the Endocrine Society (San Diego, CA)

\section{Grants, Awards, \& Recognition:}


Recipient of Diversity Supplement Award funded by Eunice Kennedy Shriver National Institute of Child Health and Human Development, NIH grant R01 HD039916, 2014

Attendee and Recipient of 2015 Early Career Forum and Travel Award provided by the Endocrine Society, March $4^{\text {th }}, 2015$, San Diego, CA 